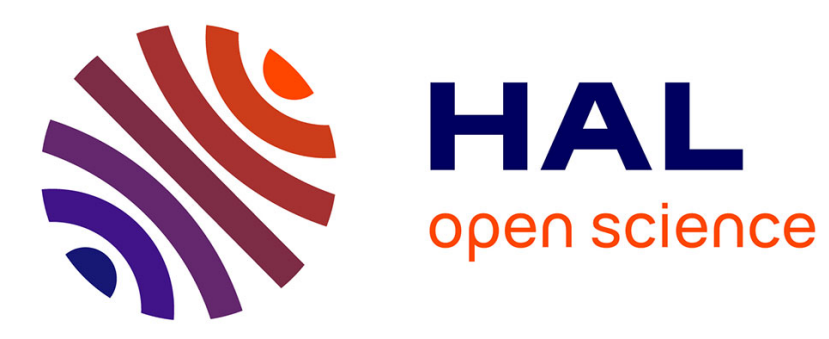

\title{
Calix[4]arene-fused phospholes
}

Fethi Elaieb, David Sémeril, Dominique Matt, Michel Pfeffer, Pierre-Antoine Bouit, Muriel Hissler, Christophe Gourlaouen, Jack Harrowfield

\section{To cite this version:}

Fethi Elaieb, David Sémeril, Dominique Matt, Michel Pfeffer, Pierre-Antoine Bouit, et al.. Calix[4]arene-fused phospholes. Dalton Transactions, 2017, 46 (30), pp.9833-9845. 10.1039/C7DT01899A . hal-01558093

\section{HAL Id: hal-01558093}

\section{https://hal-univ-rennes1.archives-ouvertes.fr/hal-01558093}

Submitted on 7 Jul 2017

HAL is a multi-disciplinary open access archive for the deposit and dissemination of scientific research documents, whether they are published or not. The documents may come from teaching and research institutions in France or abroad, or from public or private research centers.
L'archive ouverte pluridisciplinaire HAL, est destinée au dépôt et à la diffusion de documents scientifiques de niveau recherche, publiés ou non, émanant des établissements d'enseignement et de recherche français ou étrangers, des laboratoires publics ou privés. 


\section{Page of contents}

\section{Calix[4] arene-fused phospholes}

A calix[4]arene-based biarylphosphine has been synthesised and catalytically converted into two diastereomeric, calixarene-fused phospholes.
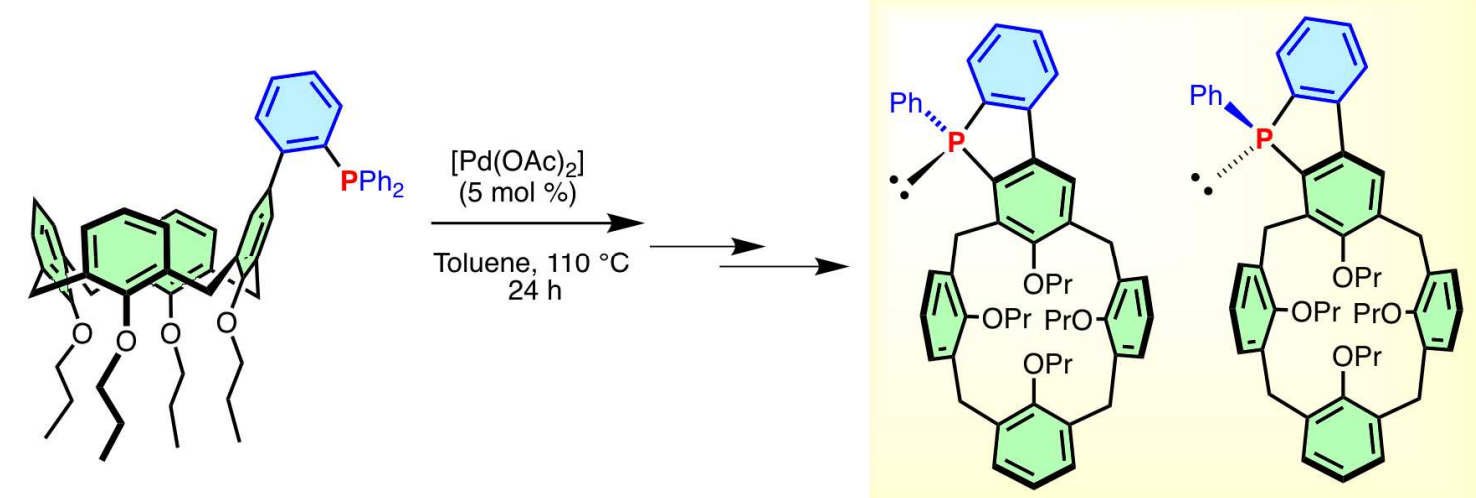


\section{Calix[4]arene-fused phospholes $\uparrow$}

Fethi Elaieb, ${ }^{\mathrm{a}}$ David Sémeril, ${ }^{* \mathrm{a}}$ Dominique Matt, ${ }^{* \mathrm{a}}$ Michel Pfeffer, ${ }^{\mathrm{b}}$ Pierre-Antoine Bouit, ${ }^{\mathrm{c}}$ Muriel Hissler, ${ }^{* c}$ Christophe Gourlaouen ${ }^{\text {, }}$, and Jack Harrowfield ${ }^{\mathrm{e}}$

An upper rim, $o$-(diphenylphosphinyl)phenyl-substituted calix[4]arene has been prepared and its coordinative properties investigated. When heated in the presence of palladium, the new biarylphosphine undergoes conversion into two diasteromeric, calixarene-fused phospholes. In both, the $\mathrm{P}$ lone pair adopts a fixed orientation with respect to the calixarene core. The more hindered phosphole (8), i.e. the one with the endo-oriented lone pair (cone angle $150^{\circ}-175^{\circ}$ ), forms complexes having their metal centre positioned very near the calixarene unit but outside the cavity, this inducing an unusual chemical shift of one of the methylenic $\mathrm{ArCH}_{2} \mathrm{Ar}$ protons owing to interactions with the metal centre. As expected for dibenzophospholes, the complex [Rh(acac)(CO)•8], when combined with one equivalent of free $\mathbf{8}$, efficiently catalyses the hydroformylation of styrene, the catalytic system displaying high regioselectivity in favour of the branched aldehyde (b/l ratio up to 30 ). The optical and redox properties of the derivatives have also been investigated.

\section{Introduction}

Cavity-shaped molecules equipped with P(III) donor atoms have attracted increasing interest in the last two decades due to successful applications in transition metal catalysis. ${ }^{[1]}$ Notably, a number of publications have shown how the presence of a conical cavity fixed near a catalytic centre may drastically influence the outcome of carbon-carbon bond forming reactions both in terms of activity and selectivity. ${ }^{[2]}$ A current challenge in this chemistry concerns the synthesis of calix[4]arenes in the so-called cone conformation substituted by a P(III) atom having its lone pair permanently located on the endo-face of the cavity. Conical molecules with this feature are expected to result in complexes with a highly crowded metal environment, if not with a metal centre embedded in the cavity. ${ }^{[2 \mathrm{i}, 2 \mathrm{j}, 3]} \mathrm{A}$ number of conecalix[4]arenes bearing a $\mathrm{PR}_{2}$ group as upper rim substituent have already been reported, but in none of them does the $\mathrm{P}$ doublet adopt a fixed endo-orientation, this being due to the rotational freedom of the $\mathrm{PR}_{2}$ moiety about the corresponding $\mathrm{P}-\mathrm{C}_{\text {calix }}$ bond. ${ }^{[4]}$ Blocking the mobility of endo-P-conformers would certainly increase the time-averaged bulkiness of the corresponding ligand.

Here, we describe the synthesis of a calix[4]arene-based biarylphosphine and its catalytic conversion into two calix[4]arene-fused phospholes, one of them having its $\mathrm{P}$

\footnotetext{
${ }^{a}$ Laboratoire de Chimie Inorganique Moléculaire et Catalyse, Institut de Chimie (UMR 7177 CNRS), Université de Strasbourg, 1 rue Blaise Pascal, F-67008 Strasbourg Cedex, France.E-mail: dmatt@unistra.fr,eric.brenner@unistra.fr ${ }^{b}$ Laboratoire de Chimie et Systémique Organométallique, Institut de Chimie (UMR 7177 CNRS), Université de Strasbourg, 1 rue Blaise Pascal, F-67008 Strasbourg Cedex, France.

${ }^{c}$ Institut des Sciences Chimiques de Rennes (UMR 6226 CNRS), Université de Rennes 1, Groupe "Phosphore et Matériaux Moléculaires", Campus de Beaulieu, 263, avenue du Général Leclerc, F-35042 Rennes Cedex, France

${ }^{d}$ Laboratoire de Chimie Quantique, Institut de Chimie (UMR 7177 CNRS), Université de Strasbourg, 1 rue Blaise Pascal, F67008 Strasbourg, France

${ }^{e}$ Institut de Science et Ingénierie Supramoléculaire (ISIS), UMR 7606 CNRS, Université de Strasbourg, $\square 8$ rue Gaspard Monge, 67083 Strasbourg cedex, France

$\uparrow C C D C 1455997 ; 1545340-1545342$. For crystallographic data in CIF or other electronic format see DOI:
} 
lone pair rigidly positioned on the concave side of the cavity. The coordinative properties of the latter were investigated towards $\mathrm{Pd}(\mathrm{II}), \mathrm{Au}(\mathrm{I})$ and $\mathrm{Rh}(\mathrm{I})$. Both ligands constitute the first examples of unsymmetrical dibenzophospholes sharing one of their benzo rings with that of a calix[4]arene receptor. ${ }^{[5]}$ Two other calixarenes linked to a phosphole unit have been reported to date but in these the phosphole unit is remote from the cavity. ${ }^{[6]}$

\section{Results and discussion}

Synthesis and coordinative properties of a phosphole precursor.

Our strategy for preparing a calix[4]arene merged with a phosphole ring was based on a recent paper by Chatani et al. where it was shown that biarylphosphines of the general formula $\mathrm{Ph}_{2} \mathrm{P}\left(o-\mathrm{Ar}-\mathrm{C}_{6} \mathrm{H}_{4}\right)$ may, in the presence of $\left[\mathrm{Pd}(\mathrm{OAc})_{2}\right]$, undergo catalytic conversion into a dibenzophosphole (Scheme 1). ${ }^{[7]}$ We anticipated that applying this methodology to the (unreported) biaryl-phosphine 3 (Scheme 2), in which the P-remote arene ring is part of a conical calix[4]arene skeleton, would result in a calixarene-fused phosphole.

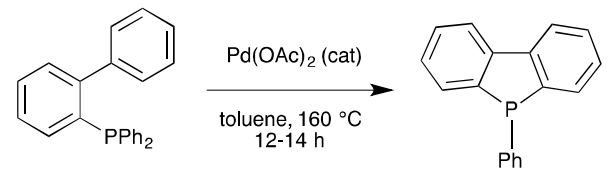

Scheme 1. Chatani's method for the catalytic synthesis of a phenyl-phosphole

The synthesis of precursor 3 was performed in two steps, as in Scheme 2. Thus, reaction of the bromoaryl-substituted calixarene $1^{[8]}$ with $n$-BuLi, followed by addition of $\mathrm{PPh}_{2} \mathrm{Cl}$ to the resulting mixture and subsequent treatment with $\mathrm{BH}_{3} \cdot \mathrm{THF}$ gave the phosphine borane adduct 2 in $75 \%$ yield. Deprotection with $\mathrm{MeOH} /$ toluene gave 3 quantitatively. The ${ }^{31} \mathrm{P}$ NMR spectrum of 3 shows a single resonance at $-12.4 \mathrm{ppm}\left(c f . \delta_{\mathrm{P}}\left(\mathrm{PPh}_{3}\right)=-4 \mathrm{ppm} ; \delta_{\mathrm{P}}\right.$ $\left.\left[\mathrm{Ph}_{2} \mathrm{P}\left(o-\mathrm{Ph}-\mathrm{C}_{6} \mathrm{H}_{4}\right)\right]=-11.9 \mathrm{ppm}\right)$. The corresponding ${ }^{1} \mathrm{H}$ NMR spectrum, which exhibits two distinct $\mathrm{AB}$ patterns for the bridging $\mathrm{ArCH}_{2} \mathrm{Ar}$ groups (both with $\mathrm{AB}$ separations of ca. 1.3 $\mathrm{ppm})$, is fully consistent with a calix[4]arene in the cone conformation. ${ }^{[9]}$

The coordinative properties of $\mathbf{3}$ towards $\mathrm{Au}(\mathrm{I})$ and $\mathrm{Pd}(\mathrm{II})$ were investigated. Thus, reaction of $\mathbf{3}$ with [AuCl(THT)] gave 4 quantitively (Scheme 3). Complex 4 was characterised by ${ }^{1} \mathrm{H}-,{ }^{13} \mathrm{C}$-, and ${ }^{31} \mathrm{P}-\mathrm{NMR}$ spectroscopy (see experimental section) as well as by a single crystal X-ray diffraction study (Fig. 1), which revealed a typical "pinched cone" structure of the calixarene core in the solid state. The $\mathrm{P}-\mathrm{Au}-\mathrm{Cl}$ rod is located outside the calixarene cavity with the gold atom lying above one of the $\mathrm{C}-\mathrm{C}$ bonds of the phosphinated phenol ring. The values of the shortest $\mathrm{Au}{ }^{\cdots} \mathrm{C}_{\text {calix }}$ separations, $3.278 \AA$ and $3.373 \AA$, are indicative of weak $\eta^{2}$ $\mathrm{Au} \cdot$ arene interactions, similar to those recently proposed by Echavarren et al. for the biarylphosphine complex $\left[\mathrm{AuCl}\left(\mathrm{Cy}{ }_{2} \mathrm{P}\left\{o-\mathrm{Ph}-\mathrm{C}_{6} \mathrm{H}_{4}\right\}\right)\right] .{ }^{[10]}$ 

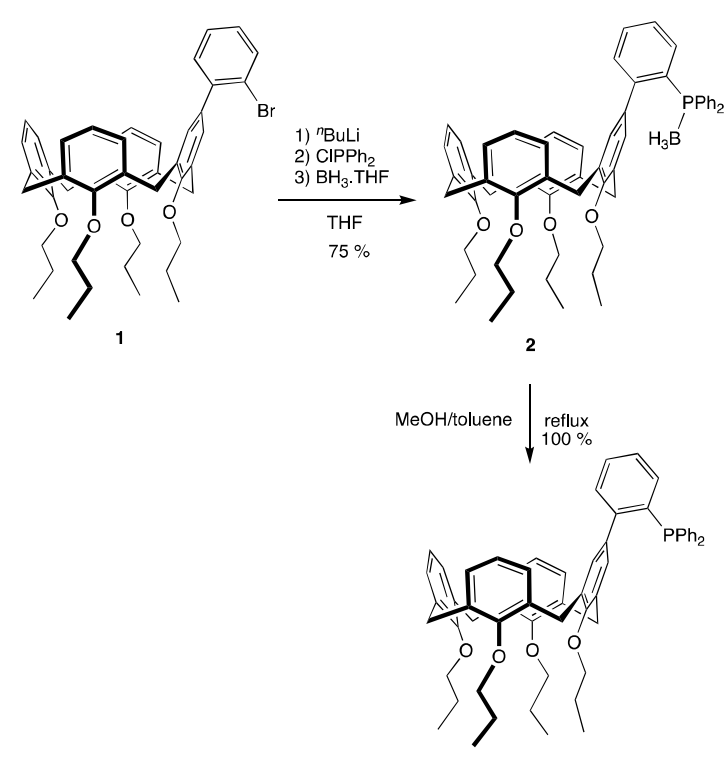

Scheme 2. Synthesis of phosphine 3
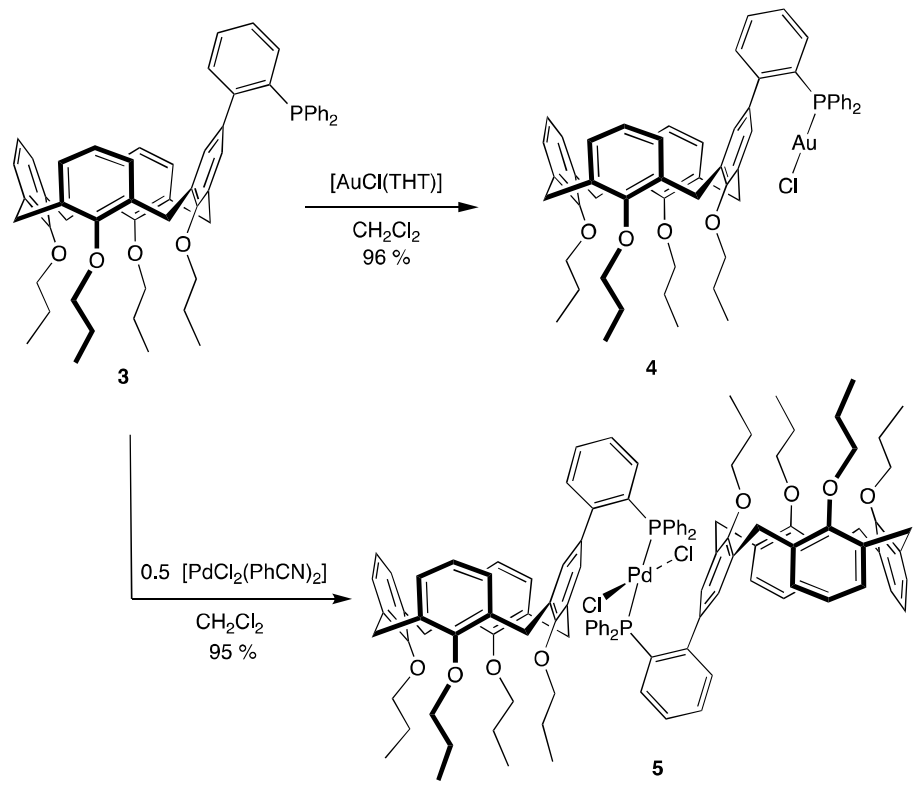

Scheme 3. Complexes obtained from phosphine 3 


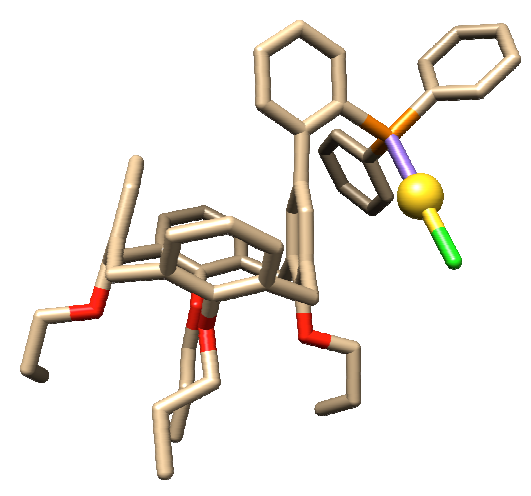

Figure 1. Molecular structure of 4.

Reaction of 3 with 0.5 equiv. of $\left[\mathrm{PdCl}_{2}(\mathrm{PhCN})_{2}\right]$ in $\mathrm{CH}_{2} \mathrm{Cl}_{2}$ (Scheme 3), resulted selectively in trans-[ $\left.\mathrm{PdCl}_{2} \cdot \mathbf{3}_{2}\right](\mathbf{5})$. Spectroscopic data is fully consistent with the presumed structure of this complex (see experimental part). In particular, assignment of the trans stereochemistry was made by comparing the chemical shift of the $\mathrm{P}$ atom $\left(\delta_{\mathrm{P}}=22.3 \mathrm{ppm}\right)$ with that measured for a related complex, trans-[PdCl $\left.2\left\{\mathrm{Ph}_{2} \mathrm{P}\left(o-\mathrm{Ph}-\mathrm{C}_{6} \mathrm{H}_{4}\right)\right\}_{2}\right]\left(\delta_{\mathrm{P}}=22.3\right.$ ppm). ${ }^{[11]}$ A preliminary X-ray study confirmed this assignment.

Catalytic conversion of phosphine 3 to the calix-fused phosphole 8

Thermal treatment of a solution of $\mathbf{3}$ in toluene for $24 \mathrm{~h}$ in the presence of $\left[\mathrm{Pd}(\mathrm{OAc})_{2}\right]$ ( $5 \mathrm{~mol} \%$ ), and subsequent reaction with $\mathrm{BH}_{3}$. THF afforded the two isomeric phospholeborane adducts $6(20 \%)$ and $7(60 \%)$, which were separated by column chromatography (Scheme 4). Both compounds possess a stereogenic phosphorus atom, one bearing an exo-, the other an endo-oriented $\mathrm{BH}_{3}$ moiety (here the terms exo and endo stand respectively for a $\mathrm{BH}_{3}$ moiety directed towards the convex or concave part of the cavity). Owing to the $C_{1}$ molecular symmetry, the bridging methylene groups of each calixarene appear as four distinct $\mathrm{AB}$ patterns in the corresponding ${ }^{1} \mathrm{H}$ NMR spectra. 


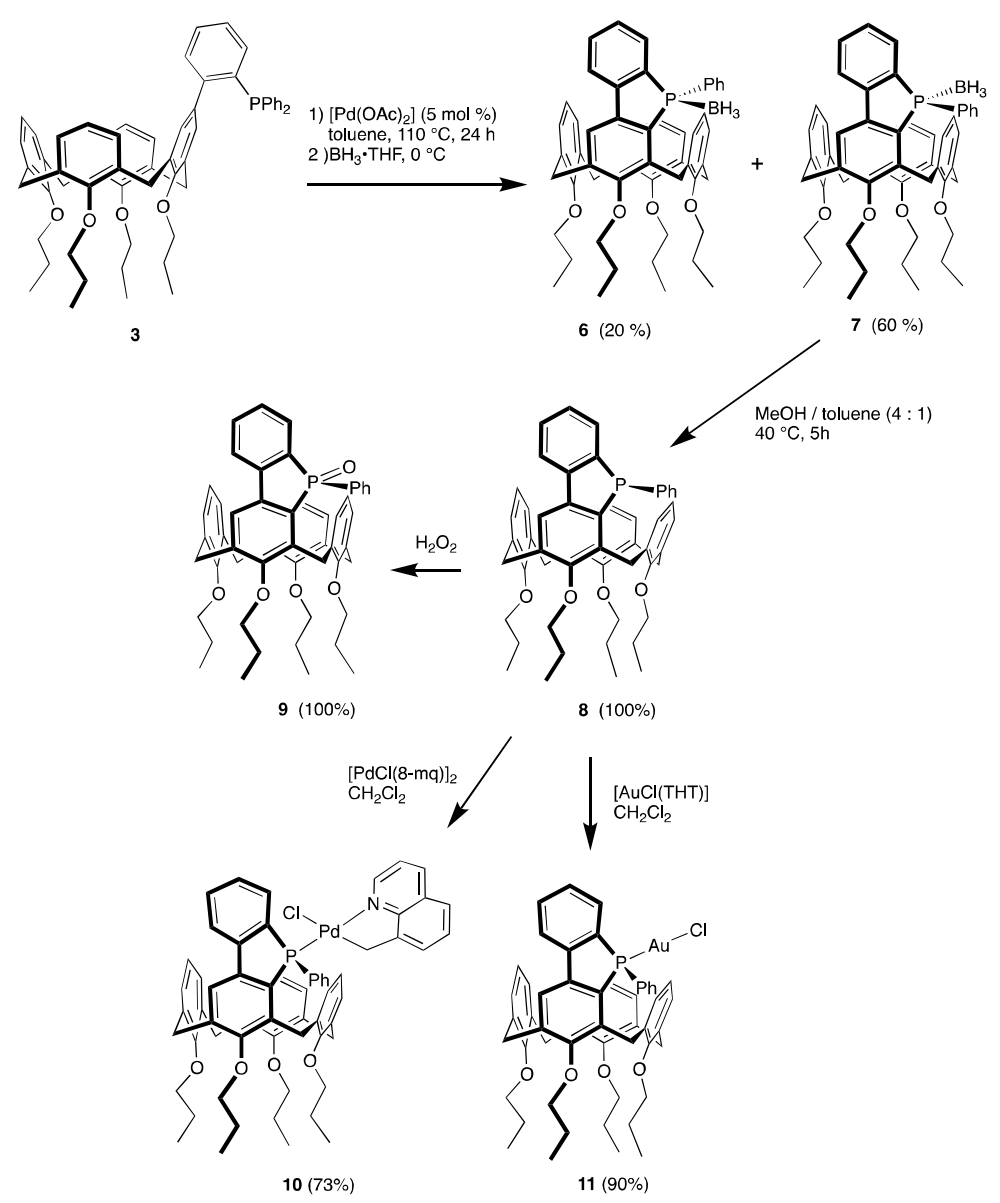

Scheme 4. Synthesis of calix-phosphole $\mathbf{8}$ and derivatives 9, 10 and 11.

As generally observed for P(III)-borane adducts, the ${ }^{31} \mathrm{P}$ NMR spectra of $\mathbf{6}$ and $\mathbf{7}$ display each a rather broad signal due to ${ }^{31} \mathrm{P}-{ }^{11} \mathrm{~B}$ coupling. Remarkably, while all aromatic protons of 7 are to be found in the range 7.92-6.04 ppm, the ${ }^{1} \mathrm{H}$ NMR spectrum of the exo-adduct 6 displays signals at higher field for three aromatic protons $(5.87$ (d), 5.65 (t) and 4.71 (d)), probably owing to a ring current effect exerted by the endo-oriented $\mathrm{PPh}$ ring on the three $\mathrm{H}$ atoms of the phenoxy ring closest to the phosphorus atom. Note that both calixarenes are inherently chiral, and therefore must each form as a racemic mixture. It is also important that, as shown previously, ${ }^{[12]}$ when the above reaction was performed with analogues of $\mathbf{3}$ bearing either a $\mathrm{PCy}_{2}$ or a $\mathrm{P}^{\mathrm{i}} \mathrm{Pr}_{2}$ substituent (instead of $\mathrm{PPh}_{2}$ ), no phosphole formation occurred.

Phosphole-borane deprotection was achieved only for endo adduct 7. A very efficient deprotection method consisted of reacting a toluene solution of 7 with $\mathrm{MeOH}$ at $40{ }^{\circ} \mathrm{C}$ for $5 \mathrm{~h}$ (Scheme 4). After heating, the solution was evaporated to dryness, affording pure 8 quantitatively. The phosphorus atom of $\mathbf{8}$ gives a peak at $-11.5 \mathrm{ppm}$ in the ${ }^{31} \mathrm{P}$ NMR spectrum. Prolonged heating of a $\mathrm{CDCl}_{3}$ solution of $\mathbf{8}$ at temperatures above $45{ }^{\circ} \mathrm{C}$ induced the very slow formation of the isomer resulting from pyramidal inversion at phosphorus (appearance of a signal at $-13.9 \mathrm{ppm}$ ). The ultimate proof for the endo stereochemistry of 7 came from an X-ray diffraction study (Fig. 2) performed on the corresponding oxide 9, which can be 
obtained by reacting 8 with $\mathrm{H}_{2} \mathrm{O}_{2}$ (Scheme 4). A determination of the Tolman cone angle of the phosphole-P based on the solid state data of 9 led to a value of ca. $150^{\circ}$. As shown in Fig. 2 , in the solid, the calixarene core of $\mathbf{9}$ adopts a typical "flattened cone" conformation in which two facing phenoxy rings are roughly parallel while the other two make an angle of ca. $75^{\circ}$. In fact, in solution the time-averaged cone angle of $\mathbf{8}$ is likely to be significantly higher than $150^{\circ}$, as conical calixarenes are known to undergo a "breathing motion" in which the facing phenoxy rings alternately come close together then move away from each other (giving rise to the so-called flattened cone / flattened cone equilibrium ${ }^{[1 \mathrm{a}]}$ ). Thus, a simulation with Spartan ${ }^{[13]}$ showed that the highest possible cone angle of 8 is $175^{\circ}$. For comparison, both 1,3,5-triphenylphosphole and $\mathrm{PPh}_{3}$ have a cone angle of $\left.145^{\circ} .{ }^{[5,}, 14\right]$ Determination of the percent buried volume of $\mathbf{8}$ using the SambVca tool ${ }^{[15]}$ led to a value of 35.0 (vs. 31.7 for $\mathrm{PPh}_{3}$ ). The corresponding steric map (Fig. 3) clearly established the proximity of the calixarenyl-P lone pair and the calixarene unit.

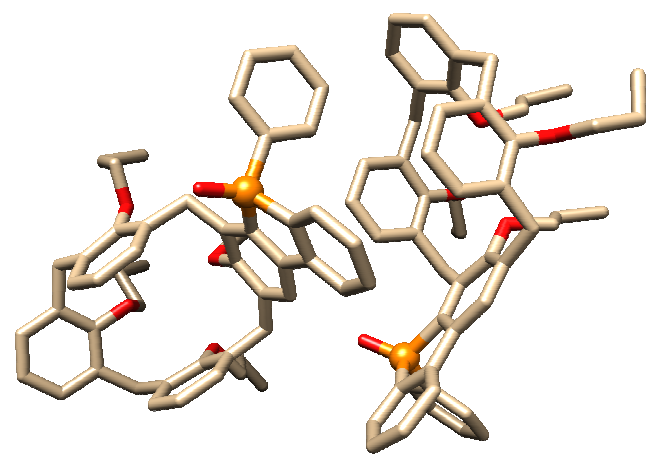

Figure 2. Solid state structure of 9. The two conformers seen in the solid form a kryptoracemate. ${ }^{[16]}$ The dihedral angles between the facing phenoxy rings are $14.3^{\circ}$ and $79.1^{\circ}$, respectively, in conformer $\mathrm{A}$, and $5.9^{\circ}$ and $74.6^{\circ}$, respectively, in conformer $\mathrm{B}$.

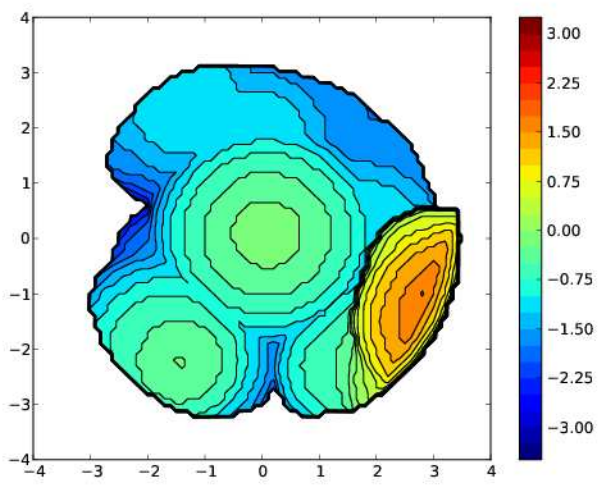


Figure 3. Steric map of $\mathbf{8}$ (determined from the X-ray structure of 11). View along the P-lone pair, taken as $\mathrm{z}$ axis (located in the middle of the Figure). The red-orange domain corresponds to the calixarene moiety. The coloured scale indicates the height on the $\mathrm{z}$ axis.

To obtain insight into its coordinative behaviour, phosphole 8 was reacted with the cyclopalladated complex $[\mathrm{PdCl}(8-\mathrm{mq})]_{2}(8-\mathrm{mqH}=8$-methylquinoline $)$. This reaction afforded complex 10 in 73\% isolated yield. In the ${ }^{31} \mathrm{P}$ NMR spectrum, the phosphorus atom is observed at $25.7 \mathrm{ppm}$, a normal value for $\left[\mathrm{PdCl}(8-\mathrm{mq})\right.$ (phosphine)] complexes. ${ }^{[17]} \mathrm{In}$ accord with the $C_{1}$ molecular symmetry, the Pd-bound $\mathrm{CH}_{2}$ group of $\mathbf{1 0}$ appears as an $\mathrm{ABX}$ spectrum in the ${ }^{1} \mathrm{H}$ NMR spectrum, with $\delta_{\mathrm{A}}=3.12 \mathrm{ppm}$ and $\delta_{\mathrm{B}}=2.42 \mathrm{ppm}\left(J(\mathrm{BA})=14.5 \mathrm{~Hz} ;{ }^{3} J(\mathrm{PA})=0 \mathrm{~Hz}\right.$ and $\left.{ }^{3} J(\mathrm{~PB})=7.5 \mathrm{~Hz}\right)$. The $\mathrm{PdCH}^{\mathrm{B}}$ signal at $2.41 \mathrm{ppm}$ is shifted somewhat upfield when compared with those of other $[\mathrm{PdCl}(8-\mathrm{mq})($ phosphine)] complexes found in the literature (typical $\delta$ around $3.2 \mathrm{ppm}) .^{[17]}$ The observed shielding is likely to reflect the magnetic anisotropy created by the flat dibenzophospholyl unit located beneath one of the $\mathrm{PdCH}_{2}$ atoms. This interpretation is consistent with the data inferred from the solid state structure of $\mathbf{1 0}$ (vide infra). An unusual feature which reflects the metal/cavity contiguity concerns the AB pattern of one of the four bridging $\mathrm{ArCH}_{2} \mathrm{Ar}$ groups, the B signal of which has undergone a strong downfield shift upon complexation $\left(\delta_{\mathrm{B}}=4.52 \mathrm{ppm}\right.$, instead of an expected value around 3.0 $\mathrm{ppm}$ ), this leading to an $\mathrm{AB}$ separation of only $0.17 \mathrm{ppm}$. The other three $\mathrm{ArCH}_{2} \mathrm{Ar}$ signals show the normal pattern with $\mathrm{AB}$ separations of about $1.3 \mathrm{ppm}$, in accord with those usually observed for conical calix[4]arenes. In fact, owing to the fixed orientation of the P lone pair in 8, complexation of the "PdCl(8-mq)" moiety positions the $\mathrm{Pd}-\mathrm{Cl}$ bond close to one of the $\mathrm{ArCH}_{2}$ groups, thereby allowing: a) the metal-bound $\mathrm{Cl}$ atom to weakly interact with the equatorial $\mathrm{CH}$ atom; b) the metal atom to create an anagostic $\mathrm{CH}$...Pd bond, and c) the phosphorus atom to give rise to a van der Waals interaction with the equatorial $\mathrm{ArCH}$ atom. All three interactions are compatible with the observed downfield shift. Note that anagostic bonds, which are electrostatic interactions in nature, are well documented in palladium chemistry. ${ }^{[18]}$

The structure of complex $\mathbf{1 0}$ was established by a single-crystal X-ray diffraction study (Fig. 4). The study confirmed that the P-Pd vector lies on the concave side of the calixarene and revealed that the metallacyclic unit lies out of the pinched cavity. In the crystal, two molecules (A and B) are present, which display notable differences. In molecule A the quinolylinyl group lies as expected in the metal plane, while in $\mathrm{B}$ it is bent by ca. $36^{\circ}$ towards the A molecule so as to enable $\pi-\pi$ stacking interactions with the neighbouring quinolinyl plane (shortest intermolecular C...C distances: $3.24 \AA, 3.25 \AA$ ).
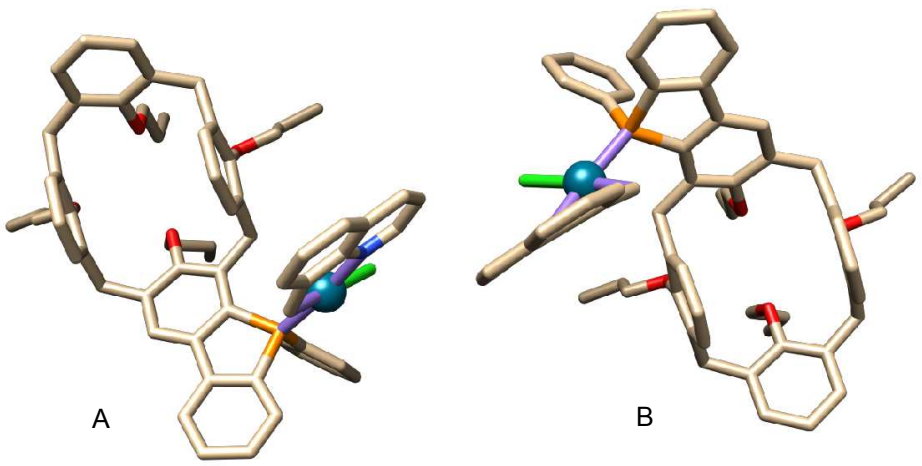

Figure 4. Solid state structure of the phosphole palladium complex $\mathbf{1 0}$ showing the two inequivalent molecules present in the unit cell. 
The study further confirmed the close proximity of both the $\mathrm{Pd}$ and $\mathrm{Cl}$ atoms to an equatorial $\mathrm{ArCH} \mathrm{H}_{2} \mathrm{Ar}$ atom of the calixarene core. The corresponding $\mathrm{Pd} . . . \mathrm{H}_{\mathrm{eq}}(3.05 \AA$ in $\mathrm{A}$ and $3.01 \AA$ in B) and $\mathrm{Cl} . . . \mathrm{H}_{\text {eq }}(3.0 \AA$ in $\mathrm{A}$ and $3.45 \AA$ in $\mathrm{B})$ separations are compatible with the above postulated weak interactions, although at the upper limit for such interactions. However, due to the flexibility of the calixarene core, the time-averaged separations may be shorter in solution than those seen in the solid. DFT optimisation starting from the X-ray structure led to a $\mathrm{H}_{\text {eq.... }} \mathrm{Cl}$ separation of $2.63 \AA$, a value which is fully consistent with an hydrogen bond (electrostatic interaction). The same calculation further established an electrostatic $\mathrm{Pd}$... $\mathrm{H}_{\mathrm{eq}}$ interaction (2.76 $\AA$; see SI), as well a P... H $\mathrm{H}_{\mathrm{eq}}$ dispersion interaction $(2.88 \AA$ ).

Finally, in accord with the observation of an upfield-shifted $\mathrm{Pd}-\mathrm{CH}$ signal, in both molecules a $\mathrm{CH}$ atom sits in the shielding zone of the flat phospholyl unit (distance to the plane: $2.78 \AA$ in $\mathrm{A} ; 2.45 \AA$ in $\mathrm{B}$ ).

To determine whether replacement of the "PdCl(8-mq)" moiety in $\mathbf{1 0}$ by a smaller metal fragment would modify the NMR signature of the $\mathrm{ArCH}_{2}$ group closest to the metal, we prepared complex 11 (Scheme 4, Fig. 6), which was obtained quantitatively by reacting 8 with $[\mathrm{AuCl}(\mathrm{THT})](\mathrm{THT}=$ tetrahydrothiophene). Its solid state structure was established by an X-ray diffraction study (Fig. 5). As for 10, the ${ }^{1} \mathrm{H}$ NMR spectrum of $\mathbf{1 1}$ shows 4 different $\mathrm{AB}$

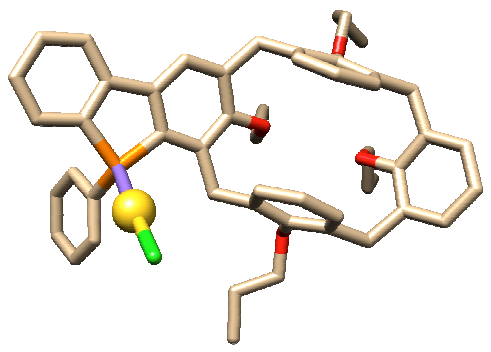

Figure 5. Molecular structure of the gold phosphole complex 11.

systems for the methylene bridges, three of which have their $\mathrm{A}$ and $\mathrm{B}$ parts separated by a $\Delta_{\mathrm{AB}}$ value of ca. $1.3 \mathrm{ppm}$ (see experimental part). The fourth $\mathrm{ArCH}_{2}$ group displays a $\Delta_{\mathrm{AB}}$ of 0.57 ppm, vs. $0.15 \mathrm{ppm}$ in 10. The smaller $\Delta_{\mathrm{AB}}$ value found for $\mathbf{1 0}$ (vs. 11) may reflect the M...Cl interaction occurring in this complex and its absence in 11. The fact that the $\Delta_{\mathrm{AB}}$ value in $\mathbf{1 1}$ still remains significantly smaller than $1.3 \mathrm{ppm}$ could not be rationalised by DFT. Interestingly, these calculations revealed the existence of another favourable conformer, which possibly facilitates reversible dissociation of the $\mathrm{AuCl}$ unit (note, the methylene $\mathrm{AB}$ patterns of $\mathbf{1 1}$ are very similar to those of free phosphole 8). 

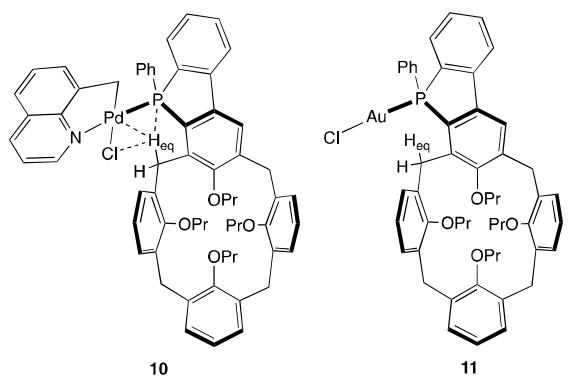

Figure 6. Possible interactions (dashed lines) involving an equatorial $\mathrm{ArCH}$ atom in $\mathbf{1 0}$ and the formula of 11

\section{Styrene hydroformylation with phosphole 8}

Dibenzo[b,d]phosphole 8 can be regarded as a triarylphosphine, and as such justifies its use in catalytic reactions. ${ }^{[19]}$ In order to assess $\mathbf{8}$ as a ligand for styrene hydroformylation, we prepared the mono-phosphole complex $[\mathrm{Rh}(\mathrm{acac})(\mathrm{CO})(\mathbf{1 0})](\mathbf{1 2})$, which was obtained by reacting $\left[\mathrm{Rh}(\mathrm{acac})(\mathrm{CO})_{2}\right]$ with 1 equiv. of 8 (Scheme 5). Spectroscopic data are fully consistent with the proposed structure. Thus, for example, the IR spectrum of $\mathbf{1 2}$ shows a strong absorption band at $1975 \mathrm{~cm}^{-1}$ for the CO ligand and the ${ }^{31} \mathrm{P}$ NMR spectrum shows a doublet at $56.0 \mathrm{ppm}(J(\mathrm{PRh})=172 \mathrm{~Hz})$ for the phosphorus atom. As for 10, the ${ }^{1} \mathrm{H} N M R$ spectrum of 12 features four $\mathrm{AB}$ patterns for the methylene $\mathrm{ArCH}_{2}$ groups, three with a $\Delta_{\mathrm{AB}}$ value of ca. $1.3 \mathrm{ppm}$, the fourth with an $\mathrm{AB}$ separation of only $0.22 \mathrm{ppm}$. The existence of a tight $\mathrm{AB}$ pattern may here be attributed to a strong $\mathrm{CH}$... $\mathrm{O}_{\text {acac }}$ interaction, as inferred from a DFT calculation. The latter calculation rules out an anagostic $\mathrm{CH}$...Rh bond (although $\mathrm{CH}$ anagostic interactions with $\mathrm{Rh}$ have been reported ${ }^{[20]}$ ).
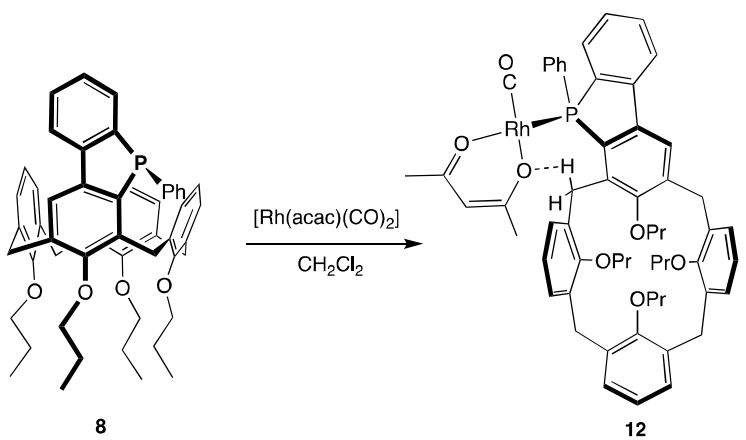

Scheme 5. Synthesis of rhodium complex 12

Catalytic runs with 12 were carried out in toluene at $60{ }^{\circ} \mathrm{C}$ under a $\mathrm{H}_{2} / \mathrm{CO}(1: 1)$ pressure of 30 bar and with a $\mathrm{Rh} /$ styrene ratio of 1000 (Table 1). Using 12 alone as catalyst resulted in a $69.0 \%$ styrene conversion after $7 \mathrm{~h}$ (Table 1, entry 1). As usual for Rh/phosphine hydroformylation catalysts, adding one equivalent of free ligand to the complex induced a significant activity increase, the styrene conversion reaching then $81.7 \%$ after $7 \mathrm{~h}$ (Table 1 , entry 2). The TOF determined after $1 \mathrm{~h}$ was 160 mol(styrene) $\operatorname{mol}(\mathrm{Rh})^{-1} \mathrm{~h}^{-1}$, vs. 75 mol(styrene) $\operatorname{mol}(\mathrm{Rh})^{-1} \mathrm{~h}^{-1}$ when using $\mathrm{PPh}_{3}$ under the same conditions. We noted that addition of a second equivalent of phosphole induced a slight decrease in activity with respect 
to the runs carried out with one equivalent of 8 (Table 1, entry 3 ). High regioselectivity in favour of the branched aldehyde (superior to those reported for other unsymmetrical benzophospholes ${ }^{[19]}$ ) was observed for each run, the branched/linear ratio amounting to 96.8 : 3.2 in the best case (Table 1, entry 3). In comparison, $\mathrm{PPh}_{3}$ resulted in a b/l ratio of $93.5: 6.5$. Similar good performances were observed with the substrates 4-fluoro-styrene and $4-{ }^{t} \mathrm{Bu}-$ styrene (Table 1, entries 5 and 6). No hydrogenation products (ethylbenzene, 2phenylpropanol) were detected in these experiments.

Table 1. Rhodium-catalysed hydroformylation of vinyl arenes ${ }^{[\mathrm{a}]}$

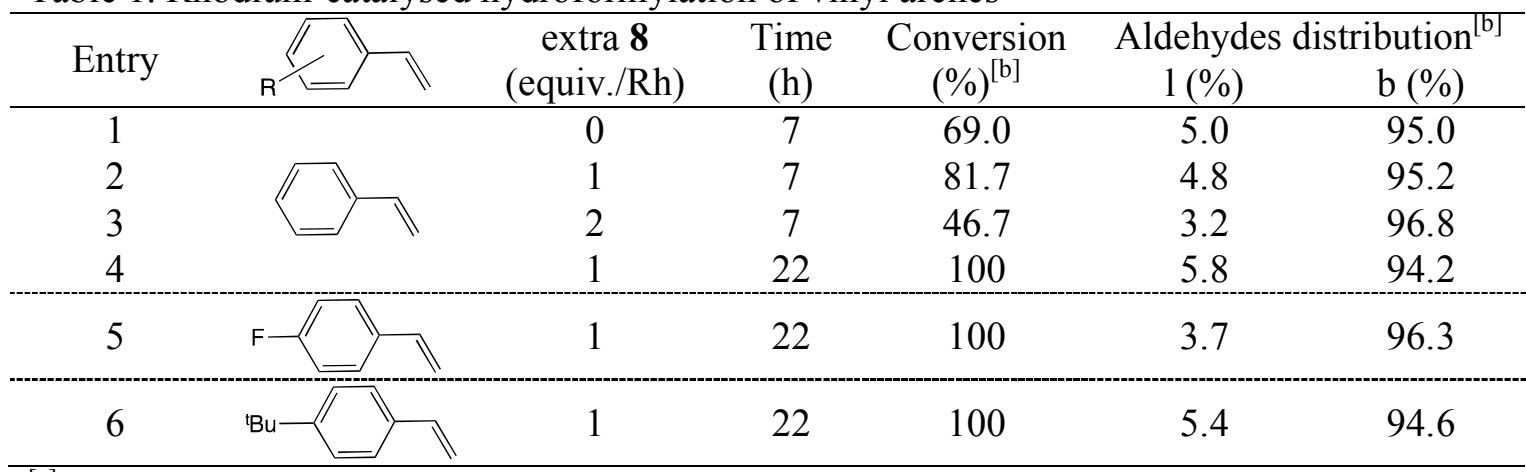

${ }^{\text {[a] }}$ Conditions: complex $12(2 \mu \mathrm{mol}), \mathbf{8}$, vinyl arene $(2 \mathrm{mmol})$, toluene $/ n$-decane $(20 \mathrm{~mL} / 0.25$ $\mathrm{mL}), \mathrm{P}\left(\mathrm{CO} / \mathrm{H}_{2}\right)=30$ bar $\left(\mathrm{CO} / \mathrm{H}_{2} 1: 1 \mathrm{v} / \mathrm{v}\right), 60^{\circ} \mathrm{C} ;{ }^{[\mathrm{b}]}$ determined by $\mathrm{GC}$ using decane as internal standard.

\section{Photophysical and electrochemical properties of phosphole oxide 9 and gold complex 11}

The following studies were undertaken to quantify the influence of the calixarene moiety on the electronic properties of the phosphole ring. The optical properties of the calixphosphole derivatives 9 and $\mathbf{1 1}$ were investigated by means of electronic absorption and fluorescence spectroscopy in dichloromethane. Their absorption spectra exhibit both a broad $\pi-\pi^{*}$ transition with a moderate extinction coefficient at 345 and $349 \mathrm{~nm}$, respectively (Fig. 4 and Table 2). The observed bands are characteristic of P-bridged biphenyl derivatives, ${ }^{[21]}$ and, as expected, an analogous band could not be detected for the phosphine complex 4 (Fig. S3). We further noted that the absorption bands are red-shifted compared to that of 5-phenyldibenzophosphole oxide (DBPO) (Fig. 7) taken as reference (9, $\Delta \lambda=13 \mathrm{~nm} ; \mathbf{1 1}, \Delta \lambda=17 \mathrm{~nm})$, thus revealing that the presence of the calixarene core induces a lowering of the HOMO-LUMO gap.

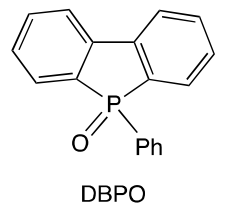

Figure 7: Structure of DBPO

Phosphole oxide 9 and gold complex 11 display similar fluorescence spectra (Fig. 8) with emission maxima centered at 412 and $415 \mathrm{~nm}$, respectively. In both cases, the excitation spectra are similar to the absorption spectra (Fig. S1 and S2) and the Stokes shifts are 
moderate $\left(\mathbf{9}, \Delta \bar{v}=4557 \mathrm{~cm}^{-1} ; \mathbf{1 1}, \Delta \bar{v}=4714 \mathrm{~cm}^{-1}\right)$, suggesting some rearrangement of these molecules upon photoexcitation. As for the absorption properties, fluorescence arises from the dibenzophosphole core (note that the phosphine complex 4 shows no luminescence) and the emission maxima are red-shifted compared to those of the DBPO $\left(\mathbf{9}, \Delta \lambda_{\mathrm{em}}=46 \mathrm{~nm} ; \mathbf{1 1}, \Delta \lambda_{\mathrm{em}}\right.$ $=49 \mathrm{~nm})$. The fluorescence quantum yield measured for complex 11 is lower $(\phi=0.01)$ than that measured for phosphole oxide $\mathbf{9}$, which turned out to be an efficient fluorophore $(\phi=$ 0.33). Compound 9 also emits as a thin film and the solid-state photoluminescence is almost superimposable on that of the solution (Figure S1). This latter observation is consistent with the absence of fluorophore stacking interactions in the solid state (see experimental part).

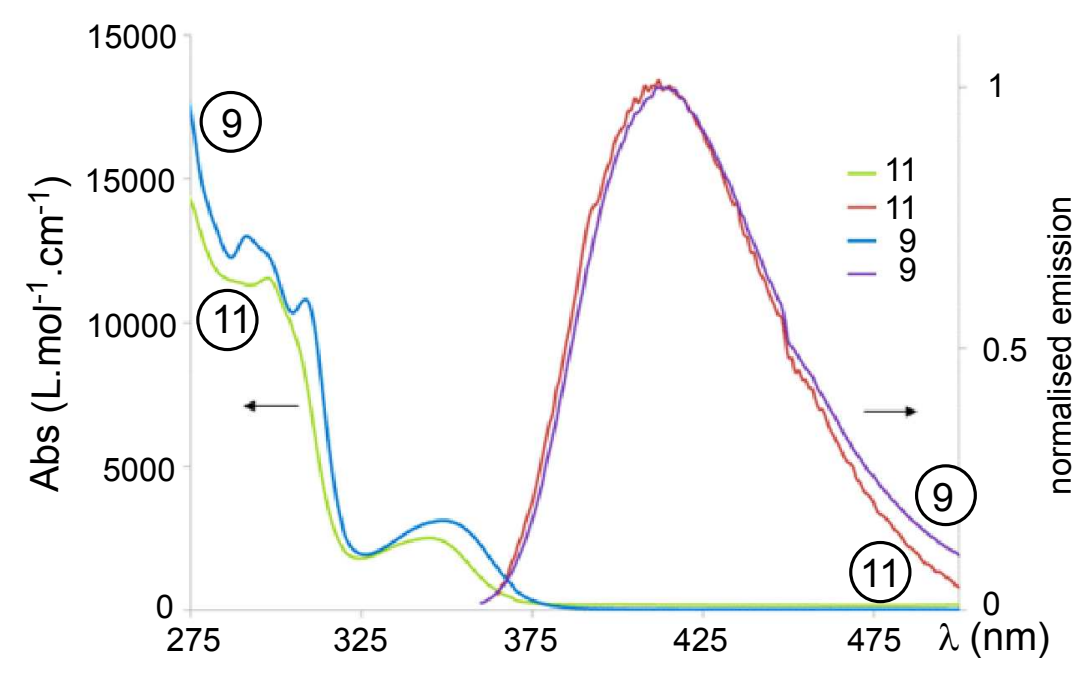

Figure 8: Electronic absorption (blue and green) and emission (violet and red) spectra of compounds 9 and 11 in dilute $\mathrm{CH}_{2} \mathrm{Cl}_{2}$ solutions

Cyclic voltammetry was further used to study the redox properties of $\mathbf{9}$ and $\mathbf{1 1}$ (Table 2 ). Both compounds display an irreversible oxidation wave, at $+1.03 \mathrm{~V}$ and $+1.17 \mathrm{~V}$, respectively. A quasi-reversible reduction can be seen at $-2.67 \mathrm{~V}$ for 9 , while the reduction of compound $11(-2.67 \mathrm{~V})$ is irreversible. Note that no reduction was observed for the phosphine complex 4. These data, when compared to those of DBPO and DBPAuCl (Table 2) indicate that 9 and $\mathbf{1 1}$ are easier to oxidise and more difficult to reduce than the two reference compounds, this reflecting the electron-donating behaviour of the calixarene core towards the dibenzophosphole unit.

Table 2: Optical and electrochemical data for $\mathbf{9}$ and $\mathbf{1 1}$

\begin{tabular}{cccccccc}
\hline & $\begin{array}{c}\lambda_{\text {abs }} \\
(\mathrm{nm})^{\mathrm{a}}\end{array}$ & $\begin{array}{c}\varepsilon \\
\left(\mathrm{L} \cdot \mathrm{mol}^{-1} \cdot \mathrm{cm}^{-1}\right)^{\mathrm{a}}\end{array}$ & $\begin{array}{c}\lambda_{\text {em }} \\
(\mathrm{nm})^{\mathrm{a}}\end{array}$ & $\Phi^{\mathrm{a}, \mathrm{b}}$ & $\begin{array}{c}\lambda_{\text {film }} \\
(\mathrm{nm})\end{array}$ & $\begin{array}{c}\mathrm{E}^{\mathrm{ox}} \\
{[\mathrm{V} \mathrm{vs} \mathrm{Fe}]^{\mathrm{c}}}\end{array}$ & $\begin{array}{c}\mathrm{E}^{\text {red }} \\
{[\mathrm{V} \text { vs Fe] }}\end{array}$ \\
\hline $\mathbf{9}$ & 349 & 2500 & 415 & 0.33 & 405 & $+1,03$ & $-2,67^{\mathrm{e}}$ \\
DBPO $^{[21]}$ & 345 & 2150 & 412 & 0.01 & - & $+1,17$ & $-2,64$ \\
& 332 & 2900 & 366 & 0.042 & - & - & $-2.35^{\mathrm{c}}$
\end{tabular}


DBPAuCl $^{[21\rfloor} 333 \quad 366 \quad 0.134 \quad-\quad-2.26^{\mathrm{f}, \mathrm{c}}$

a) Measured in dichloromethane b) Measured relative to quinine sulfate $\left(\mathrm{H}_{2} \mathrm{SO}_{4}, 0.1 \mathrm{M}\right), \phi=0.55$. c) All potentials were obtained during cyclic voltammetric investigations in $0.2 \mathrm{M} \mathrm{Bu}_{4} \mathrm{NPF}_{6}$ in $\mathrm{CH}_{2} \mathrm{Cl}_{2}$. Platinum electrode diameter $1 \mathrm{~mm}$, sweep rate: $200 \mathrm{mV} \mathrm{s}^{-1}$. All potentials are referenced to the reversible formal potential of ferrocene/ferrocenium d) All potentials were obtained during cyclic voltammetric investigations in $0.1 \mathrm{M}$ $\mathrm{Bu}_{4} \mathrm{NPF}_{6}$ in THF. Platinum electrode diameter $1 \mathrm{~mm}$, sweep rate: $200 \mathrm{mV} \mathrm{s}^{-1}$. All potentials are referenced to the reversible formal potential of ferrocene/ferrocenium. e) quasi reversible. f) $\mathrm{Ep}_{\mathrm{c}}$

\section{Conclusions}

Thermal treatment of the new calixarene-based biarylphosphine 3 in the presence of catalytic amounts of palladium results in two separable, calixarene-fused phospholes with directionally rigid $\mathrm{P}$ lone pairs. With the sterically encumbered endo- $P$-calixarene $\mathbf{8}$, metal complexes are formed in which the metal centre sits very close to the calixarenyl substituent, thereby creating binding interactions with but one methylene $\mathrm{ArCH}$ atom of the calixarene core. The dibenzophosphole complex $[\mathrm{Rh}(\mathrm{acac})(\mathrm{CO})(\mathbf{8})]$ efficiently catalyses the hydroformylation of styrene with production of high proportions of branched aldehyde, reflecting the steric effect of the adjacent cavity which may pass through various weak interactions. Ligand $\mathbf{8}$ constitutes the first example of a calix[4]arene integrating a phosphole functionality in the cavity wall. As revealed by photophysical and electrochemical studies, the calixarene moiety behaves as an electron donating group with respect to the phosphole unit, endowing it with unique properties compared to known systems. In particular, 9 turned out to be an efficient fluorophore both in solution and in the solid state. Future work will aim at exploiting such molecules as sensors.

\section{Experimental Section}

General Methods: All manipulations were performed in Schlenk-type flasks under dry argon. Solvents were dried by conventional methods and distilled immediately prior to use. $\mathrm{CDCl}_{3}$ was passed down a $5 \mathrm{~cm}$ thick alumina column and stored under nitrogen over molecular sieves $\left(4 \AA\right.$ ). Routine ${ }^{1} \mathrm{H},{ }^{13} \mathrm{C}\left\{{ }^{1} \mathrm{H}\right\}$ and ${ }^{31} \mathrm{P}\left\{{ }^{1} \mathrm{H}\right\}$ NMR spectra were recorded with Bruker FT spectrometers (AVANCE 400 and 500). ${ }^{1} \mathrm{H}$ chemical shifts are referenced to residual protiated solvent signals $\left(\delta=7.26 \mathrm{ppm}\right.$ for $\mathrm{CDCl}_{3}$ and $7.11 \mathrm{ppm}$ for $\left.\mathrm{C}_{6} \mathrm{D}_{6}\right)$, ${ }^{13} \mathrm{C}$ chemical shifts are reported relative to deuteriated solvent signals $\left(\delta=77.16 \mathrm{ppm}\right.$ for $\mathrm{CDCl}_{3}$ and 128.06 for $\mathrm{C}_{6} \mathrm{D}_{6}$ ) and the ${ }^{31} \mathrm{P}$ NMR spectroscopic data are given relative to external $\mathrm{H}_{3} \mathrm{PO}_{4}$. Chemical shifts and coupling constants are reported in ppm and $\mathrm{Hz}$, respectively. Elemental analyses were performed by the Service de Microanalyse, Institut de Chimie, Université de Strasbourg. 5-(2-bromophenyl)-25,26,27,28-tetrapropyloxycalix[4]arene (1), ${ }^{[8]}$ $[\mathrm{AuCl}(\mathrm{THT})],{ }^{[22]}\left[\mathrm{PdCl}_{2}(\mathrm{PhCN})_{2}\right]^{[23]}$ and $[\mathrm{PdCl}(8-\mathrm{mq})]_{2}{ }^{[24]}$ (8-mqH = 8-methylquinoline) were prepared according to literature procedures.

General procedure for the hydroformylation experiments. The hydroformylation experiments were carried out in a glass-lined, $100 \mathrm{~mL}$ stainless steel autoclave containing a magnetic stirring bar. In a typical run, the autoclave was charged with 12 (2 $\mu \mathrm{mol})$ and extra 
$\mathbf{8}$, then closed and flushed twice with vacuum/ $\mathrm{N}_{2}$. Toluene $(20 \mathrm{~mL})$, the vinyl arene $(2 \mathrm{mmol})$ and decane $(0.25 \mathrm{~mL})$ were added under $\mathrm{N}_{2}$. The autoclave was then pressurised $(30 \mathrm{bar}$, $\mathrm{CO} / \mathrm{H}_{2} 1: 1 \mathrm{v} / \mathrm{v}$ ) and heated at $60^{\circ} \mathrm{C}$. At the end of each run, the autoclave was cooled to room temperature before being depressurised slowly. A sample was taken and analysed by GC using a WCOT fused silica column (25 $\mathrm{m}$ x $0.25 \mathrm{~mm})$.

Optical and electrochemical properties. UV-Visible spectra were recorded at room temperature on a specord 205 spectrophotometer. The emission and excitation spectra measurements were recorded on a FL 920 Edimburgh Instrument and corrected for the response of the photomultiplier. Quantum yields were calculated relative to quinine sulfate $(\phi$ $=0.55$ in $\mathrm{H}_{2} \mathrm{SO}_{4} 0.1 \mathrm{M}$ ). The electrochemical studies were carried out under argon using an Eco Chemie Autolab PGSTAT 30 potentiostat for cyclic voltammetry with the three-electrode configuration: the working electrode was a platinum disk, the reference electrode was a saturated calomel electrode and the counter-electrode a platinum wire. All potential were internally referenced to the ferrocene/ ferrocenium couple. For the measurements, concentrations of $10^{-3} \mathrm{M}$ of the electroactive species were used in freshly distilled and degassed dichloromethane and 0.2 $\mathrm{M}$ tetrabutylammonium hexafluorophosphate

[5-(2-Diphenylphosphanyl-phenyl)-25,26,27,28-tetrapropyloxycalix[4]arene] borane (2): $n$-Butyllithium (1.6 M in hexane, $0.62 \mathrm{~mL}, 1.00 \mathrm{mmol}$ ) was slowly added to a solution of 5(2-bromophenyl)-25,26,27,28-tetrapropyloxycalix[4] arene $\mathbf{1}(0.600 \mathrm{~g}, 0.80 \mathrm{mmol})$ in THF (50 $\mathrm{mL})$ at $-78{ }^{\circ} \mathrm{C}$. After $0.5 \mathrm{~h}, \mathrm{ClPPh}_{2}(0.24 \mathrm{~mL}, 1.30 \mathrm{mmol})$ was added and the resulting mixture stirred at $65^{\circ} \mathrm{C}$ for $16 \mathrm{~h}$. The reaction was allowed to reach $0^{\circ} \mathrm{C}$, then $\mathrm{BH}_{3}$.THF $(1 \mathrm{M}$ in THF, 2 $\mathrm{mL}, 2 \mathrm{mmol}$ ) was added. After stirring for $5 \mathrm{~h}$ at room temperature, the solvent was evaporated under reduced pressure. The crude product was purified by column chromatography $\left(\mathrm{CH}_{2} \mathrm{Cl}_{2} /\right.$ petroleum ether, $\left.20: 80 \mathrm{v} / \mathrm{v}\right)$ to afford 2 as a white solid $(0.521 \mathrm{~g}$, yield $75 \% ; R_{\mathrm{f}}=3.84, \mathrm{CH}_{2} \mathrm{Cl}_{2} /$ petroleum ether, 20:80 v/v). ${ }^{1} \mathrm{H} \mathrm{NMR}\left(\mathrm{CDCl}_{3}, 400 \mathrm{MHz}\right): \delta=$ 7.51-7.41 (m, 6H, arom. $\left.\mathrm{CH}, \mathrm{P}\left(\mathrm{BH}_{3}\right) \mathrm{Ph}_{2}\right), 7.38-7.32\left(\mathrm{~m}, 5 \mathrm{H}\right.$, arom. $\mathrm{CH}, \mathrm{P}\left(\mathrm{BH}_{3}\right) \mathrm{Ph}_{2}$ and $\left.\mathrm{C}_{6} \mathrm{H}_{4}\right), 7.29-7.19$ (m, 2H, arom. $\left.\mathrm{CH}, \mathrm{C}_{6} \mathrm{H}_{4}\right), 6.82$ (d, $2 \mathrm{H}$, arom. $\mathrm{CH}$, calixarene, ${ }^{3} \mathrm{~J}=6.4 \mathrm{~Hz}$ ), 6.72-6.69 (m, 1H, arom. $\left.\mathrm{CH}, \mathrm{C}_{6} \mathrm{H}_{4}\right), 6.66\left(\mathrm{t}, 2 \mathrm{H}\right.$, arom. $\mathrm{CH}$, calixarene, $\left.{ }^{3} \mathrm{~J}=7.4 \mathrm{~Hz}\right), 6.62(\mathrm{~d}$, $2 \mathrm{H}$, arom. $\mathrm{CH}$, calixarene, $\left.{ }^{3} \mathrm{~J}=7.2 \mathrm{~Hz}\right), 6.40$ (s, 3H, arom. $\mathrm{CH}$, calixarene), 5.99 (s, 2H, arom. $\mathrm{CH}$, calixarene), 4.44 and 3.13 (AB spin system, $4 \mathrm{H}, \mathrm{ArCH}_{2} \mathrm{Ar},{ }^{2} J=13.2 \mathrm{~Hz}$ ), 4.27 and 2.83 (AB spin system, $\left.4 \mathrm{H}, \mathrm{ArCH}_{2} \mathrm{Ar},{ }^{2} J=13.2 \mathrm{~Hz}\right), 3.92\left(\mathrm{t}, 4 \mathrm{H}, \mathrm{OCH}_{2},{ }^{3} J=7.8 \mathrm{~Hz}\right), 3.74(\mathrm{t}, 2 \mathrm{H}$, $\left.\mathrm{OCH}_{2},{ }^{3} J=7.2 \mathrm{~Hz}\right), 3.66\left(\mathrm{t}, 2 \mathrm{H}, \mathrm{OCH}_{2},{ }^{3} J=7.2 \mathrm{~Hz}\right), 1.99-1.85\left(\mathrm{~m}, 8 \mathrm{H}, \mathrm{CH}_{2} \mathrm{CH}_{3}\right), 1.09$ (t, 3H, $\mathrm{CH}_{2} \mathrm{CH}_{3},{ }^{3} \mathrm{~J}=7.6 \mathrm{~Hz}$ ), 1.04 (t, $\left.3 \mathrm{H}, \mathrm{CH}_{2} \mathrm{CH}_{3},{ }^{3} \mathrm{~J}=7.6 \mathrm{~Hz}\right), 0.93$ (t, $6 \mathrm{H}, \mathrm{CH}_{2} \mathrm{CH}_{3},{ }^{3} \mathrm{~J}=7.4 \mathrm{~Hz}$ ); ${ }^{13} \mathrm{C}\left\{{ }^{1} \mathrm{H}\right\}$ NMR $\left(\mathrm{CDCl}_{3}, 125 \mathrm{MHz}\right): \delta=157.14$ (s, arom Cq-O), 157.09 (s, arom Cq-O), 135.89-121.85 (arom. C's), $76.95\left(\mathrm{~s}, \mathrm{OCH}_{2}\right), 76.90\left(\mathrm{~s}, \mathrm{OCH}_{2}\right), 76.54\left(\mathrm{~s}, \mathrm{OCH}_{2}\right), 30.99$ (s, $\left.\mathrm{ArCH} \mathrm{H}_{2} \mathrm{Ar}\right), 30.74$ (s, $\left.\mathrm{ArCH} \mathrm{H}_{2} \mathrm{Ar}\right), 23.43\left(\mathrm{CH}_{2} \mathrm{CH}_{3}\right), 23.09\left(\mathrm{CH}_{2} \mathrm{CH}_{3}\right), 10.69\left(\mathrm{CH}_{2} \mathrm{CH}_{3}\right), 10.61$ $\left(\mathrm{CH}_{2} \mathrm{CH}_{3}\right), 10.08\left(\mathrm{CH}_{2} \mathrm{CH}_{3}\right) ;{ }^{31} \mathrm{P}\left\{{ }^{1} \mathrm{H}\right\} \mathrm{NMR}\left(\mathrm{CDCl}_{3}, 162 \mathrm{MHz}\right): \delta=21.1$ (br. s, $\left.\mathrm{P}\left(\mathrm{BH}_{3}\right)\right)$ ppm; MS (ESI): $m / z=889.45[\mathrm{M}+\mathrm{Na}]^{+}$expected isotopic profile; elemental analysis calcd (\%) for $\mathrm{C}_{58} \mathrm{H}_{64} \mathrm{O}_{4} \mathrm{~PB}(\mathrm{Mr}=866.91)$ : C 80.36, H 7.44; found (\%): C 80.50, H 7.55.

5-(2-Diphenylphosphanyl-phenyl)-25,26,27,28-tetrapropyloxycalix[4]arene

(3): $\quad \mathrm{A}$ solution of [5-(2-phosphanyl-phenyl)-25,26,27,28-tetrapropyloxycalix[4]arene] borane (0.520 $\mathrm{g}, 0.60 \mathrm{mmol})$ in $\mathrm{MeOH} /$ toluene $(1: 4$ mixture, $15 \mathrm{~mL}$ ) was refluxed for $5 \mathrm{~h}$. After cooling to 
room temperature, the solution was evaporated to dryness and the residue dried overnight under vacuum at $40^{\circ} \mathrm{C}$ to afford quantitatively phosphine $3(0.511 \mathrm{~g}$, yield $100 \%) .{ }^{1} \mathrm{H}$ NMR $\left(\mathrm{CDCl}_{3}, 400 \mathrm{MHz}\right): \delta=7.34-7.28\left(\mathrm{~m}, 7 \mathrm{H}\right.$, arom. $\mathrm{CH}, \mathrm{PPh}_{2}$ and $\left.\mathrm{C}_{6} \mathrm{H}_{4}\right), 7.24-7.13(\mathrm{~m}, 5 \mathrm{H}$, arom. $\mathrm{CH}, \mathrm{PPh}_{2}$ and $\left.\mathrm{C}_{6} \mathrm{H}_{4}\right), 7.00-6.96\left(\mathrm{~m}, 1 \mathrm{H}\right.$, arom. $\left.\mathrm{CH}, \mathrm{C}_{6} \mathrm{H}_{4}\right), 6.94-6.90(\mathrm{~m}, 1 \mathrm{H}$, arom. $\mathrm{CH}$, $\left.\mathrm{C}_{6} \mathrm{H}_{4}\right), 6.67\left(\mathrm{~d}, 2 \mathrm{H}\right.$, arom. $\mathrm{CH}$, calixarene, $\left.{ }^{3} \mathrm{~J}=6.9 \mathrm{~Hz}\right), 6.62-6.57(\mathrm{~m}, 1 \mathrm{H}$, arom. $\mathrm{CH}$, calixarene), $6.56\left(\mathrm{~s}, 2 \mathrm{H}\right.$, arom. $\mathrm{CH}$, calixarene), $6.51\left(\mathrm{~d}, 2 \mathrm{H}\right.$, arom. $\mathrm{CH}$, calixarene, ${ }^{3} J=6.6$ $\mathrm{Hz}), 6.42\left(\mathrm{t}, 2 \mathrm{H}\right.$, arom. $\mathrm{CH}$, calixarene, $\left.{ }^{3} \mathrm{~J}=7.5 \mathrm{~Hz}\right), 6.24$ (d, $2 \mathrm{H}$, arom. $\mathrm{CH}$, calixarene, ${ }^{3} J=$ $7.2 \mathrm{~Hz}$ ), 4.45 and 3.14 (AB spin system, $4 \mathrm{H}, \mathrm{ArCH}_{2} \mathrm{Ar},{ }^{2} J=13.2 \mathrm{~Hz}$ ), 4.38 and 3.01 (AB spin system, $\left.4 \mathrm{H}, \mathrm{ArCH} \mathrm{H}_{2} \mathrm{Ar},{ }^{2} J=13.2 \mathrm{~Hz}\right), 3.88\left(\mathrm{t}, 2 \mathrm{H}, \mathrm{OCH}_{2},{ }^{3} J=7.8 \mathrm{~Hz}\right), 3.82\left(\mathrm{t}, 6 \mathrm{H}, \mathrm{OCH}_{2},{ }^{3} J=\right.$ $7.8 \mathrm{~Hz}$ ), 1.99-1.86 (m, 8H, $\left.\mathrm{CH}_{2} \mathrm{CH}_{3}\right), 1.03$ (t, 9H, $\left.\mathrm{CH}_{2} \mathrm{CH}_{3},{ }^{3} \mathrm{~J}=7.5 \mathrm{~Hz}\right), 0.96$ (t, 3H, $\left.\mathrm{CH}_{2} \mathrm{CH}_{3},{ }^{3} \mathrm{~J}=7.2 \mathrm{~Hz}\right) ;{ }^{13} \mathrm{C}\left\{{ }^{1} \mathrm{H}\right\} \mathrm{NMR}\left(\mathrm{CDCl}_{3}, 125 \mathrm{MHz}\right): \delta=156.89$ (s, arom Cq-O), 156.39 (s, arom Cq-O), 156.15 (s, arom Cq-O), 148.79-121.94 (arom. C's), $77.11\left(\mathrm{~s}, \mathrm{OCH}_{2}\right), 77.05$ $\left(\mathrm{s}, \mathrm{OCH}_{2}\right), 31.09(\mathrm{~s}, \mathrm{ArCH}+\mathrm{Ar}), 31.05(\mathrm{~s}, \mathrm{ArCH} 2 \mathrm{Ar}), 23.40\left(\mathrm{CH}_{2} \mathrm{CH}_{3}\right), 10.52\left(\mathrm{CH}_{2} \mathrm{CH}_{3}\right), 10.45$ $\left(\mathrm{CH}_{2} \mathrm{CH}_{3}\right) ;{ }^{31} \mathrm{P}\left\{{ }^{1} \mathrm{H}\right\}$ NMR $\left(\mathrm{CDCl}_{3}, 162 \mathrm{MHz}\right): \delta=-12.4\left(\mathrm{~s}, \mathrm{PPh}_{2}\right) \mathrm{ppm} ; \mathrm{MS}(\mathrm{ESI}): m / z=$ $891.41[\mathrm{M}+\mathrm{K}]^{+}$expected isotopic profiles; elemental analysis calcd (\%) for $\mathrm{C}_{58} \mathrm{H}_{61} \mathrm{O}_{4} \mathrm{P}(\mathrm{Mr}$ = 853.08): C 81.66, H 7.21; found (\%): C 81.48, H 7.08.

Chlorido [5-(2-diphenylphosphanyl-phenyl)-25,26,27,28-tetrapropyloxycalix[4]arene] gold (I) (4): A solution of [ $\mathrm{AuCl}(\mathrm{THT})](0.037 \mathrm{~g}, 0.17 \mathrm{mmol})$ in $\mathrm{CH}_{2} \mathrm{Cl}_{2}(25 \mathrm{~mL})$ was added to a stirred solution of $3(0.100 \mathrm{~g}, 0.17 \mathrm{mmol})$ in $\mathrm{CH}_{2} \mathrm{Cl}_{2}(25 \mathrm{~mL})$. After stirring for $0.5 \mathrm{~h}$, the solution was concentrated to ca. $2 \mathrm{~mL}$ and $n$-hexane $(20 \mathrm{~mL})$ was added. A white precipitate formed, which was separated by filtration and dried under vacuum $(0.122 \mathrm{~g}$, yield $96 \%) .{ }^{1} \mathrm{H}$ NMR $\left(\mathrm{CDCl}_{3}, 500 \mathrm{MHz}\right): \delta=7.58-7.56\left(\mathrm{~m}, 2 \mathrm{H}\right.$, arom. $\left.\mathrm{CH}, \mathrm{PPh}_{2}\right)$, 7.49-7.44 (m, 8H, arom. $\mathrm{CH}, \mathrm{PPh}_{2}$ ), 7.37 (t, $1 \mathrm{H}$, arom. $\mathrm{CH}, \mathrm{C}_{6} \mathrm{H}_{4},{ }^{3} J=7.2 \mathrm{~Hz}$ ), 7.19 (t, $1 \mathrm{H}$, arom. $\mathrm{CH}, \mathrm{C}_{6} \mathrm{H}_{4},{ }^{3} J=7.5$ $\mathrm{Hz}), 6.97\left(\mathrm{~d}, 2 \mathrm{H}\right.$, arom. $\mathrm{CH}$, calixarene, $\left.{ }^{3} \mathrm{~J}=7.0 \mathrm{~Hz}\right), 6.86-6.82\left(\mathrm{~m}, 1 \mathrm{H}\right.$, arom. $\left.\mathrm{CH}, \mathrm{C}_{6} \mathrm{H}_{4}\right)$, 6.74-6.70 (m, 1H, arom. $\left.\mathrm{CH}, \mathrm{C}_{6} \mathrm{H}_{4}\right), 6.71\left(\mathrm{t}, 2 \mathrm{H}\right.$, arom. $\mathrm{CH}$, calixarene, $\left.{ }^{3} J=7.5 \mathrm{~Hz}\right), 6.62(\mathrm{~d}$, $2 \mathrm{H}$, arom. $\mathrm{CH}$, calixarene, $\left.{ }^{3} \mathrm{~J}=7.0 \mathrm{~Hz}\right), 6.31\left(\mathrm{t}, 1 \mathrm{H}\right.$, arom. $\mathrm{CH}$, calixarene, $\left.{ }^{3} J=7.2 \mathrm{~Hz}\right), 6.26$ (d, 2H, arom. $\mathrm{CH}$, calixarene, $\left.{ }^{3} J=7.2 \mathrm{~Hz}\right), 5.84$ (s, 2H, arom. $\mathrm{CH}$, calixarene), 4.46 and 3.14 (AB spin system, $4 \mathrm{H}, \mathrm{ArCH} \mathrm{H}_{2} \mathrm{Ar},{ }^{2} J=13.0 \mathrm{~Hz}$ ), 4.39 and 2.97 (AB spin system, $4 \mathrm{H}, \mathrm{ArCH} \mathrm{H}_{2} \mathrm{Ar}$, $\left.{ }^{2} J=13.5 \mathrm{~Hz}\right), 4.05-3.96\left(\mathrm{~m}, 4 \mathrm{H}, \mathrm{OCH}_{2}\right), 3.90\left(\mathrm{t}, 2 \mathrm{H}, \mathrm{OCH}_{2},{ }^{3} \mathrm{~J}=6.5 \mathrm{~Hz}\right), 3.69\left(\mathrm{t}, 2 \mathrm{H}, \mathrm{OCH}_{2}\right.$, $\left.{ }^{3} J=7.0 \mathrm{~Hz}\right), 2.02-1.95\left(\mathrm{~m}, 4 \mathrm{H}, \mathrm{CH}_{2} \mathrm{CH}_{3}\right), 1.95-1.86\left(\mathrm{~m}, 4 \mathrm{H}, \mathrm{CH}_{2} \mathrm{CH}_{3}\right), 1.15\left(\mathrm{t}, 3 \mathrm{H}, \mathrm{CH}_{2} \mathrm{CH}_{3}\right.$, $\left.{ }^{3} J=7.2 \mathrm{~Hz}\right), 1.08\left(\mathrm{t}, 3 \mathrm{H}, \mathrm{CH}_{2} \mathrm{CH}_{3},{ }^{3} \mathrm{~J}=7.5 \mathrm{~Hz}\right), 0.91\left(\mathrm{t}, 6 \mathrm{H}, \mathrm{CH}_{2} \mathrm{CH}_{3},{ }^{3} \mathrm{~J}=7.2 \mathrm{~Hz}\right) ;{ }^{13} \mathrm{C}\left\{{ }^{1} \mathrm{H}\right\}$ $\mathrm{NMR}\left(\mathrm{CDCl}_{3}, 125 \mathrm{MHz}\right): \delta=157.66$ (s, arom Cq-O), 156.08 (s, arom Cq-O), 155.63 (s, arom Cq-O), 149.00-121.80 (arom. C's), $77.76\left(\mathrm{~s}, \mathrm{OCH}_{2}\right), 77.15\left(\mathrm{~s}, \mathrm{OCH}_{2}\right), 76.61\left(\mathrm{~s}, \mathrm{OCH}_{2}\right), 31.05$ (s, $\left.\mathrm{ArCH} \mathrm{H}_{2} \mathrm{Ar}\right), 30.94$ (s, $\left.\mathrm{ArCH} \mathrm{H}_{2} \mathrm{Ar}\right), 23.75\left(\mathrm{CH}_{2} \mathrm{CH}_{3}\right), 23.58\left(\mathrm{CH}_{2} \mathrm{CH}_{3}\right), 23.08\left(\mathrm{CH}_{2} \mathrm{CH}_{3}\right)$, $11.04\left(\mathrm{CH}_{2} \mathrm{CH}_{3}\right), 10.86\left(\mathrm{CH}_{2} \mathrm{CH}_{3}\right), 10.01\left(\mathrm{CH}_{2} \mathrm{CH}_{3}\right) ;{ }^{31} \mathrm{P}\left\{{ }^{1} \mathrm{H}\right\} \mathrm{NMR}\left(\mathrm{CDCl}_{3}, 162 \mathrm{MHz}\right): \delta=$ $26.9\left(\mathrm{~s}, \mathrm{PPh}_{2}\right) \mathrm{ppm}$; elemental analysis calcd $(\%)$ for $\mathrm{C}_{58} \mathrm{H}_{61} \mathrm{O}_{4} \mathrm{PAuCl}(\mathrm{Mr}=1085.50): \mathrm{C}$ 64.17, H 5.66; found (\%): C 64.08, H 5.54.

trans-P,P-Dichlorido-bis[5-(2-diphenylphosphanyl-phenyl)-25,26,27,28-tetrapropyloxycalix[4]arene] palladium (II) (5): A solution of $\left[\mathrm{PdCl}_{2}(\mathrm{PhCN})_{2}\right](0.020 \mathrm{~g}, 0.052 \mathrm{mmol})$ in $\mathrm{CH}_{2} \mathrm{Cl}_{2}(10 \mathrm{~mL})$ was added to a stirred solution of $3(0.088 \mathrm{~g}, 0.103 \mathrm{mmol})$ in $\mathrm{CH}_{2} \mathrm{Cl}_{2}(10$ $\mathrm{mL})$. After stirring for $0.5 \mathrm{~h}$, the solution was concentrated to ca. $2 \mathrm{~mL}$ and $n$-hexane $(20 \mathrm{~mL})$ 
was added. The resulting yellow precipitate was separated by filtration and dried under vacuum (0.072 g, yield $95 \%)$. ${ }^{1} \mathrm{H}$ NMR $\left(\mathrm{C}_{6} \mathrm{D}_{6}, 400 \mathrm{MHz}\right): \delta=8.08$ (q, $2 \mathrm{H}$, arom. $\mathrm{CH}, \mathrm{C}_{6} \mathrm{H}_{4}$, ${ }^{3} J=6.8 \mathrm{~Hz}$ ), 8.00-7.96 (m, 6H, arom. $\left.\mathrm{CH}, \mathrm{PPh}_{2}\right), 7.14-7.10$ (m, 6H, arom. $\mathrm{CH}$, calixarene), 7.08-7.704 (m, 6H, arom. $\left.\mathrm{CH}, \mathrm{C}_{6} \mathrm{H}_{4}\right), 7.04-7.00\left(\mathrm{~m}, 14 \mathrm{H}\right.$, arom. $\left.\mathrm{CH}, \mathrm{PPh}_{2}\right), 6.79$ (s, 6H, arom. $\mathrm{CH}$, calixarene), 6.71-6.69 (m, 4H, arom. $\mathrm{CH}$, calixarene), 6.63-6.62 (m, 6H, arom. $\mathrm{CH}$, calixarene), 4.56 and 3.17 (AB spin system, $8 \mathrm{H}, \mathrm{ArCH}_{2} \mathrm{Ar},{ }^{2} \mathrm{~J}=13.5 \mathrm{~Hz}$ ), 4.43 and 3.14 (AB spin system, $\left.8 \mathrm{H}, \mathrm{ArCH}_{2} \mathrm{Ar},{ }^{2} J=13.5 \mathrm{~Hz}\right), 3.88-3.84\left(\mathrm{~m}, 8 \mathrm{H}, \mathrm{OCH}_{2}\right), 3.83-3.78(\mathrm{~m}, 8 \mathrm{H}$, $\mathrm{OCH}_{2}$ ), 1.99-1.88 (m, 16H, $\left.\mathrm{CH}_{2} \mathrm{CH}_{3}\right), 1.03\left(\mathrm{t}, 6 \mathrm{H}, \mathrm{CH}_{2} \mathrm{CH}_{3},{ }^{3} \mathrm{~J}=7.5 \mathrm{~Hz}\right), 0.94$ (t, $12 \mathrm{H}$, $\left.\mathrm{CH}_{2} \mathrm{CH}_{3},{ }^{3} \mathrm{~J}=7.5 \mathrm{~Hz}\right), 0.93\left(\mathrm{t}, 6 \mathrm{H}, \mathrm{CH}_{2} \mathrm{CH}_{3},{ }^{3} \mathrm{~J}=7.5 \mathrm{~Hz}\right) ;{ }^{13} \mathrm{C}\left\{{ }^{1} \mathrm{H}\right\} \mathrm{NMR}\left(\mathrm{C}_{6} \mathrm{D}_{6}, 125 \mathrm{MHz}\right): \delta$ $=157.17(\mathrm{~s}$, arom Cq-O), $156.70(\mathrm{~s}$, arom Cq-O), 156.29 (s, arom Cq-O), 147.25-122.57 (arom. C's), $76.95\left(\mathrm{~s}, \mathrm{OCH}_{2}\right), 76.86\left(\mathrm{~s}, \mathrm{OCH}_{2}\right), 31.60\left(\mathrm{~s}, \mathrm{ArCH} \mathrm{H}_{2} \mathrm{Ar}\right), 31.36\left(\mathrm{~s}, \mathrm{ArCH} \mathrm{H}_{2} \mathrm{Ar}\right)$, $23.79\left(\mathrm{CH}_{2} \mathrm{CH}_{3}\right), 23.67\left(\mathrm{CH}_{2} \mathrm{CH}_{3}\right), 23.64\left(\mathrm{CH}_{2} \mathrm{CH}_{3}\right), 10.68\left(\mathrm{CH}_{2} \mathrm{CH}_{3}\right), 10.59\left(\mathrm{CH}_{2} \mathrm{CH}_{3}\right)$, $10.54\left(\mathrm{CH}_{2} \mathrm{CH}_{3}\right) ;{ }^{31} \mathrm{P}\left\{{ }^{1} \mathrm{H}\right\} \mathrm{NMR}\left(\mathrm{C}_{6} \mathrm{D}_{6}, 162 \mathrm{MHz}\right): \delta=22.3\left(\mathrm{~s}, \mathrm{PPh}_{2}\right) \mathrm{ppm} ; \mathrm{MS}(\mathrm{ESI}): \mathrm{m} / z=$ $1903.73[\mathrm{M}+\mathrm{Na}]^{+}$expected isotopic profiles; elemental analysis calcd (\%) for $\mathrm{C}_{116} \mathrm{H}_{122} \mathrm{O}_{8} \mathrm{P}_{2} \mathrm{PdCl}_{2}(M \mathrm{r}=1883.48)$ : C 73.97, H 6.53; found (\%): C 74.05, H 6.68.

Synthesis of $\quad[5-(P$-phenyl-5H-benzo $[b]$ phosphindolyl $)-25,26,27,28-$ tetrapropyloxycalix[4]arene] boranes exo-6 and endo-7: A solution of phosphine 3 (4.000 g, $4.69 \mathrm{mmol})$ and $\left[\mathrm{Pd}(\mathrm{OAc})_{2}\right](0.105 \mathrm{~g}, 0.47 \mathrm{mmol})$ in toluene $(50 \mathrm{~mL})$ was heated at $110^{\circ} \mathrm{C}$ for $24 \mathrm{~h}$. After cooling the solution to room temperature, the solvent was removed in vacuum. The crude product was then dissolved in THF. The solution was cooled to $0^{\circ} \mathrm{C}$ before addition of $\mathrm{BH}_{3}$.THF (1M in THF, $18.8 \mathrm{~mL}, 18.76 \mathrm{mmol}$ ). After stirring for $2 \mathrm{~h}$, the solution was evaporated to dryness. The residue was purified by column chromatography $\left(\mathrm{CH}_{2} \mathrm{Cl}_{2} /\right.$ petroleum ether, 5:95 v/v) to afford benzophosphole boranes $\mathbf{6}$ and 7 as white solids.

Phosphole borane 6: $\left(0.740 \mathrm{~g}\right.$, yield $20 \% ; R_{\mathrm{f}}=0.28, \mathrm{CH}_{2} \mathrm{Cl}_{2} /$ petroleum ether, 5:95 v/v); ${ }^{1} \mathrm{H}$ NMR $\left(\mathrm{CD}_{2} \mathrm{Cl}_{2}, 400 \mathrm{MHz}\right): \delta=7.96\left(\mathrm{~d}, 1 \mathrm{H}\right.$, arom. $\left.\mathrm{CH}, \mathrm{C}_{6} \mathrm{H}_{4},{ }^{3} \mathrm{~J}=7.6 \mathrm{~Hz}\right), 7.78(\mathrm{~d}, 1 \mathrm{H}$, arom. $\mathrm{CH}$, calixarene, $\left.{ }^{4} J(\mathrm{PH})=2.4 \mathrm{~Hz}\right), 7.70-7.60\left(\mathrm{~m}, 4 \mathrm{H}\right.$, arom. $\mathrm{CH}, \mathrm{P}\left(\mathrm{BH}_{3}\right) \mathrm{Ph}$ and $\left.\mathrm{C}_{6} \mathrm{H}_{4}\right), 7.43-$ $7.37\left(\mathrm{~m}, 2 \mathrm{H}\right.$, arom. $\left.\mathrm{CH}, \mathrm{P}\left(\mathrm{BH}_{3}\right) \mathrm{Ph}\right), 7.34\left(\mathrm{dt}, 2 \mathrm{H}\right.$, arom. $\left.\mathrm{CH}, \mathrm{P}\left(\mathrm{BH}_{3}\right) \mathrm{Ph},{ }^{3} J=7.6 \mathrm{~Hz}\right),{ }^{4} J(\mathrm{PH})=$ $1.6 \mathrm{~Hz}), 7.12-7.0840\left(\mathrm{~m}, 2 \mathrm{H}\right.$, arom. $\mathrm{CH}$, calixarene), $6.90\left(\mathrm{t}, 1 \mathrm{H}\right.$, arom. $\mathrm{CH}$, calixarene, ${ }^{3} \mathrm{~J}=$ $7.4 \mathrm{~Hz}), 6.18-6.1\left(\mathrm{~m}, 2 \mathrm{H}\right.$, arom. $\mathrm{CH}$, calixarene), $6.06\left(\mathrm{~d}, 1 \mathrm{H}\right.$, arom. $\mathrm{CH}$, calixarene, ${ }^{3} J=7.2$ $\mathrm{Hz}), 5.87\left(\mathrm{~d}, 1 \mathrm{H}\right.$, arom. $\mathrm{CH}$, calixarene, $\left.{ }^{3} \mathrm{~J}=7.6 \mathrm{~Hz}\right), 5.65\left(\mathrm{t}, 1 \mathrm{H}\right.$, arom. $\mathrm{CH}$, calixarene, ${ }^{3} J=$ $7.6 \mathrm{~Hz}$ ), 4.71 (d, 1H, arom. CH, calixarene, ${ }^{3} J=7.6 \mathrm{~Hz}$ ), 4.55 and 3.33 (AB spin system, $2 \mathrm{H}$, $\mathrm{ArCH}_{2} \mathrm{Ar},{ }^{2} \mathrm{~J}=14.0 \mathrm{~Hz}$ ), 4.45 and 3.58 (AB spin system, $2 \mathrm{H}, \mathrm{ArCH}_{2} \mathrm{Ar},{ }^{2} \mathrm{~J}=13.6 \mathrm{~Hz}$ ), 4.45 and 3.15 (AB spin system, $2 \mathrm{H}, \mathrm{ArCH}_{2} \mathrm{Ar},{ }^{2} \mathrm{~J}=13.6 \mathrm{~Hz}$ ), 4.39 and 3.07 (AB spin system, $2 \mathrm{H}$, $\left.\mathrm{ArCH}_{2} \mathrm{Ar},{ }^{2} \mathrm{~J}=13.4 \mathrm{~Hz}\right), 4.14-4.09\left(\mathrm{~m}, 2 \mathrm{H}, \mathrm{OCH}_{2}\right), 4.01\left(\mathrm{t}, 2 \mathrm{H}, \mathrm{OCH}_{2},{ }^{3} J=8.2 \mathrm{~Hz}\right), 3.68$ (t, $\left.2 \mathrm{H}, \mathrm{OCH}_{2},{ }^{3} \mathrm{~J}=7.0 \mathrm{~Hz}\right), 3.66-3.56\left(\mathrm{~m}, 2 \mathrm{H}, \mathrm{OCH}_{2}\right), 2.01-1.84\left(\mathrm{~m}, 8 \mathrm{H}, \mathrm{CH}_{2} \mathrm{CH}_{3}\right), 1.12(\mathrm{t}, 3 \mathrm{H}$, $\left.\mathrm{CH}_{2} \mathrm{CH}_{3},{ }^{3} \mathrm{~J}=7.4 \mathrm{~Hz}\right), 1.05\left(\mathrm{t}, 3 \mathrm{H}, \mathrm{CH}_{2} \mathrm{CH}_{3},{ }^{3} \mathrm{~J}=7.4 \mathrm{~Hz}\right), 0.88\left(\mathrm{t}, 6 \mathrm{H}, \mathrm{CH}_{2} \mathrm{CH}_{3},{ }^{3} \mathrm{~J}=7.4 \mathrm{~Hz}\right.$ ), 0.90-0.77 (m, 3H, $\left.\mathrm{P}\left(\mathrm{BH}_{3}\right)\right) ;{ }^{13} \mathrm{C}\left\{{ }^{1} \mathrm{H}\right\}$ NMR $\left(\mathrm{CD}_{2} \mathrm{Cl}_{2}, 125 \mathrm{MHz}\right): \delta=159.87$ (d, arom Cq-O, $\left.{ }^{3} J(\mathrm{CP})=11.4 \mathrm{~Hz}\right), 158.59(\mathrm{~s}$, arom Cq-O), 155.78 (s, arom Cq-O), 155.68 (s, arom Cq-O), 145.08-121.42 (arom. C's), $77.47\left(\mathrm{~s}, \mathrm{OCH}_{2}\right), 77.39\left(\mathrm{~s}, \mathrm{OCH}_{2}\right), 77.14\left(\mathrm{~s}, \mathrm{OCH}_{2}\right), 77.12$ (s, $\left.\mathrm{OCH}_{2}\right), 32.07$ (s, $\left.\mathrm{ArCH} \mathrm{H}_{2} \mathrm{Ar}\right), 31.34$ (s, $\left.\mathrm{ArCH} \mathrm{H}_{2} \mathrm{Ar}\right), 31.22$ (s, $\left.\mathrm{ArCH} \mathrm{Ar}_{2} \mathrm{Ar}\right), 29.66$ (d, $\mathrm{ArCH} \mathrm{H}_{2} \mathrm{Ar}$, $\left.{ }^{3} J(\mathrm{CP})=4.1 \mathrm{~Hz}\right), 23.97\left(\mathrm{CH}_{2} \mathrm{CH}_{3}\right), 23.48\left(\mathrm{CH}_{2} \mathrm{CH}_{3}\right), 23.31\left(\mathrm{CH}_{2} \mathrm{CH}_{3}\right), 11.12\left(\mathrm{CH}_{2} \mathrm{CH}_{3}\right)$, $11.05\left(\mathrm{CH}_{2} \mathrm{CH}_{3}\right), 10.04\left(\mathrm{CH}_{2} \mathrm{CH}_{3}\right), 9.86\left(\mathrm{CH}_{2} \mathrm{CH}_{3}\right) ;{ }^{31} \mathrm{P}\left\{{ }^{1} \mathrm{H}\right\} \mathrm{NMR}\left(\mathrm{CD}_{2} \mathrm{Cl}_{2}, 162 \mathrm{MHz}\right): \delta=$ 
23.0 (br. s, $\left.\mathrm{P} . \mathrm{BH}_{3}\right)$ ppm; elemental analysis calcd (\%) for $\mathrm{C}_{52} \mathrm{H}_{58} \mathrm{O}_{4} \mathrm{~PB}(\mathrm{Mr}=788.80)$ : $\mathrm{C}$ 79.18, H 7.41; found (\%): C 79.23, H 7.55.

Phosphole borane 7: $\left(2.219 \mathrm{~g}\right.$, yield $60 \% ; R_{\mathrm{f}}=0.26, \mathrm{CH}_{2} \mathrm{Cl}_{2} /$ petroleum ether, $\left.5: 95 \mathrm{v} / \mathrm{v}\right) ;{ }^{1} \mathrm{H}$ NMR $\left(\mathrm{CD}_{2} \mathrm{Cl}_{2}, 500 \mathrm{MHz}\right): \delta=7.91\left(\mathrm{~d}, 1 \mathrm{H}\right.$, arom. $\left.\mathrm{CH}, \mathrm{C}_{6} \mathrm{H}_{4},{ }^{3} \mathrm{~J}=8.0 \mathrm{~Hz}\right), 7.80$ (d, $1 \mathrm{H}$, arom. $\mathrm{CH}$, calixarene, $\left.{ }^{4} J(\mathrm{PH})=2.0 \mathrm{~Hz}\right), 7.67-7.59\left(\mathrm{~m}, 4 \mathrm{H}\right.$, arom. $\mathrm{CH}, \mathrm{P}\left(\mathrm{BH}_{3}\right) \mathrm{Ph}$ and $\left.\mathrm{C}_{6} \mathrm{H}_{4}\right), 7.49$ (dt, 12H, arom. $\left.\mathrm{CH}, \mathrm{C}_{6} \mathrm{H}_{4},{ }^{3} J=7.5 \mathrm{~Hz},{ }^{4} \mathrm{~J}(\mathrm{PH})=1.0 \mathrm{~Hz}\right), 7.40\left(\mathrm{dt}, 2 \mathrm{H}\right.$, arom. $\mathrm{CH}, \mathrm{P}\left(\mathrm{BH}_{3}\right) \mathrm{Ph}$, $\left.{ }^{3} J=7.7 \mathrm{~Hz},{ }^{4} J(\mathrm{PH})=2.0 \mathrm{~Hz}\right), 7.36\left(\mathrm{dt}, 1 \mathrm{H}\right.$, arom. $\mathrm{CH}, \mathrm{P}\left(\mathrm{BH}_{3}\right) \mathrm{Ph},{ }^{3} J=7.7 \mathrm{~Hz},{ }^{5} J(\mathrm{PH})=4.0$ $\mathrm{Hz}), 7.15\left(\mathrm{~d}, 2 \mathrm{H}\right.$, arom. $\mathrm{CH}$, calixarene, $\left.{ }^{3} \mathrm{~J}=7.5 \mathrm{~Hz}\right), 6.94\left(\mathrm{t}, 1 \mathrm{H}\right.$, arom. $\mathrm{CH}$, calixarene, ${ }^{3} \mathrm{~J}=$ $7.5 \mathrm{~Hz}), 6.37\left(\mathrm{~d}, 1 \mathrm{H}\right.$, arom. $\mathrm{CH}$, calixarene, $\left.{ }^{3} J=7.5 \mathrm{~Hz}\right), 6.24-6.15(\mathrm{~m}, 3 \mathrm{H}$, arom. $\mathrm{CH}$, calixarene), $6.11\left(\mathrm{~d}, 1 \mathrm{H}\right.$, arom. $\mathrm{CH}$, calixarene, $\left.{ }^{3} J=7.5 \mathrm{~Hz}\right), 6.05(\mathrm{~d}, 1 \mathrm{H}$, arom. $\mathrm{CH}$, calixarene, ${ }^{3} J=7.5 \mathrm{~Hz}$ ), 4.57 and 3.35 (AB spin system, $2 \mathrm{H}, \mathrm{ArCH}_{2} \mathrm{Ar},{ }^{2} J=13.5 \mathrm{~Hz}$ ), 4.45 and 3.17 (AB spin system, $2 \mathrm{H}, \mathrm{ArCH}_{2} \mathrm{Ar},{ }^{2} \mathrm{~J}=14.0 \mathrm{~Hz}$ ), 4.42 and 3.15 (AB spin system, $2 \mathrm{H}$, $\mathrm{ArCH}_{2} \mathrm{Ar},{ }^{2} \mathrm{~J}=13.5 \mathrm{~Hz}$ ), 4.23 and 3.51 (AB spin system, $2 \mathrm{H}, \mathrm{ArCH}_{2} \mathrm{Ar},{ }^{2} J=13.5 \mathrm{~Hz}$ ), 4.14$4.05\left(\mathrm{~m}, 2 \mathrm{H}, \mathrm{OCH}_{2}\right), 4.02\left(\mathrm{t}, 2 \mathrm{H}, \mathrm{OCH}_{2},{ }^{3} \mathrm{~J}=8.2 \mathrm{~Hz}\right), 3.71-3.66\left(\mathrm{~m}, 2 \mathrm{H}, \mathrm{OCH}_{2}\right), 3.58(\mathrm{t}, 2 \mathrm{H}$, $\left.\mathrm{OCH}_{2},{ }^{3} J=7.0 \mathrm{~Hz}\right), 2.87-1.98\left(\mathrm{~m}, 3 \mathrm{H}, \mathrm{P}\left(\mathrm{BH}_{3}\right)\right), 1.98-1.88\left(\mathrm{~m}, 6 \mathrm{H}, \mathrm{CH}_{2} \mathrm{CH}_{3}\right), 1.84-1.76(\mathrm{~m}$, $\left.6 \mathrm{H}, \mathrm{CH}_{2} \mathrm{CH}_{3}\right), 1.13$ (t, $3 \mathrm{H}, \mathrm{CH}_{2} \mathrm{CH}_{3},{ }^{3} \mathrm{~J}=7.5 \mathrm{~Hz}$ ), 1.02 (t, $3 \mathrm{H}, \mathrm{CH}_{2} \mathrm{CH}_{3},{ }^{3} \mathrm{~J}=7.5 \mathrm{~Hz}$ ), 0.87 (t, $\left.3 \mathrm{H}, \mathrm{CH}_{2} \mathrm{CH}_{3},{ }^{3} \mathrm{~J}=7.5 \mathrm{~Hz}\right), 0.85\left(\mathrm{t}, 3 \mathrm{H}, \mathrm{CH}_{2} \mathrm{CH}_{3},{ }^{3} \mathrm{~J}=7.5 \mathrm{~Hz}\right) ;{ }^{13} \mathrm{C}\left\{{ }^{1} \mathrm{H}\right\} \mathrm{NMR}\left(\mathrm{CD}_{2} \mathrm{Cl}_{2}, 125\right.$ $\mathrm{MHz}): \delta=159.91\left(\mathrm{~d}\right.$, arom $\left.\mathrm{Cq}-\mathrm{O},{ }^{3} J(\mathrm{CP})=10.8 \mathrm{~Hz}\right), 158.53(\mathrm{~s}$, arom Cq-O), 155.60 (s, arom Cq-O), 155.48 (s, arom Cq-O), 143.98-121.48 (arom. C's), $77.46\left(\mathrm{~s}, \mathrm{OCH}_{2}\right), 77.32\left(\mathrm{~s}, \mathrm{OCH}_{2}\right)$, $77.12\left(\mathrm{~s}, \mathrm{OCH}_{2}\right), 77.05\left(\mathrm{~s}, \mathrm{OCH}_{2}\right), 31.87\left(\mathrm{~s}, \mathrm{ArCH} \mathrm{H}_{2} \mathrm{Ar}\right), 31.30\left(\mathrm{~s}, \mathrm{ArCH} \mathrm{H}_{2} \mathrm{Ar}\right), 31.18$ (s, $\left.\mathrm{ArCH} \mathrm{H}_{2} \mathrm{Ar}\right), 29.73\left(\mathrm{~d}, \mathrm{ArCH} \mathrm{H}_{2} \mathrm{Ar},{ }^{3} \mathrm{~J}(\mathrm{CP})=4.9 \mathrm{~Hz}\right), 23.96\left(\mathrm{CH}_{2} \mathrm{CH}_{3}\right), 23.86\left(\mathrm{CH}_{2} \mathrm{CH}_{3}\right), 23.43$ $\left(\mathrm{CH}_{2} \mathrm{CH}_{3}\right), 23.35\left(\mathrm{CH}_{2} \mathrm{CH}_{3}\right), 11.11\left(\mathrm{CH}_{2} \mathrm{CH}_{3}\right), 10.92\left(\mathrm{CH}_{2} \mathrm{CH}_{3}\right), 9.98\left(\mathrm{CH}_{2} \mathrm{CH}_{3}\right), 9.95$ $\left(\mathrm{CH}_{2} \mathrm{CH}_{3}\right) ;{ }^{31} \mathrm{P}\left\{{ }^{1} \mathrm{H}\right\}$ NMR $\left(\mathrm{CD}_{2} \mathrm{Cl}_{2}, 162 \mathrm{MHz}\right): \delta=23.3$ (br. s, $\left.\mathrm{P} . \mathrm{BH}_{3}\right) \mathrm{ppm}$; MS (ESI): $m / z=$ $827.39[\mathrm{M}+\mathrm{K}]^{+}$expected isotopic profile; elemental analysis calcd (\%) for $\mathrm{C}_{52} \mathrm{H}_{58} \mathrm{O}_{4} \mathrm{~PB}(\mathrm{Mr}$ = 788.80): C 79.18, H 7.41; found (\%): C 79.27, H 7.58.

Phosphole 8: A solution of phosphole borane 7 (2.000 g, $2.53 \mathrm{mmol})$ in $\mathrm{MeOH} /$ toluene (1:4 mixture, $15 \mathrm{~mL}$ ) was heated at $40^{\circ} \mathrm{C}$ for $5 \mathrm{~h}$. After cooling to room temperature, the solution was evaporated to dryness and the residue dried overnight under vacuum to afford quantitatively benzophosphole $8(1.964 \mathrm{~g}$, yield $100 \%) .{ }^{1} \mathrm{H} \mathrm{NMR}\left(\mathrm{CDCl}_{3}, 400 \mathrm{MHz}\right): \delta=$ $7.86\left(\mathrm{~d}, 1 \mathrm{H}\right.$, arom. $\left.\mathrm{CH}, \mathrm{C}_{6} \mathrm{H}_{4},{ }^{3} \mathrm{~J}=7.6 \mathrm{~Hz}\right), 7.69$ (s, $1 \mathrm{H}$, arom. $\mathrm{CH}$, calixarene), 7.66-7.63 (m, $1 \mathrm{H}$, arom. $\left.\mathrm{CH}, \mathrm{C}_{6} \mathrm{H}_{4}\right), 7.41\left(\mathrm{t}, 1 \mathrm{H}\right.$, arom. $\left.\mathrm{CH}, \mathrm{C}_{6} \mathrm{H}_{4},{ }^{3} \mathrm{~J}=7.6 \mathrm{~Hz}\right), 7.42$ (t, 2H, arom. $\mathrm{CH}, \mathrm{PPh}$, ${ }^{3} J=7.6 \mathrm{~Hz}$ ), 7.33-7.28 (m, 3H, arom. $\left.\mathrm{CH}, \mathrm{PPh}\right), 7.22-7.18\left(\mathrm{~m}, 1 \mathrm{H}\right.$, arom. $\left.\mathrm{CH}, \mathrm{C}_{6} \mathrm{H}_{4}\right), 7.04$ (d, $2 \mathrm{H}$, arom. $\mathrm{CH}$, calixarene, $\left.{ }^{3} \mathrm{~J}=7.6 \mathrm{~Hz}\right), 6.79\left(\mathrm{t}, 1 \mathrm{H}\right.$, arom. $\mathrm{CH}$, calixarene, $\left.{ }^{3} J=7.2 \mathrm{~Hz}\right), 6.51$ (d, $1 \mathrm{H}$, arom. $\mathrm{CH}$, calixarene, $\left.{ }^{3} J=7.2 \mathrm{~Hz}\right), 6.31-6.26$ (m, 3H, arom. $\mathrm{CH}$, calixarene), 6.23$6.20\left(\mathrm{~m}, 2 \mathrm{H}\right.$, arom. $\mathrm{CH}$, calixarene), 4.60 and 3.34 (AB spin system, $2 \mathrm{H}, \mathrm{ArCH}_{2} \mathrm{Ar},{ }^{2} J=13.2$ $\mathrm{Hz}$ ), 4.49 and 3.19 (AB spin system, $2 \mathrm{H}, \mathrm{ArCH}_{2} \mathrm{Ar},{ }^{2} J=12.8 \mathrm{~Hz}$ ), 4.46 and 3.17 (AB spin system, $2 \mathrm{H}, \mathrm{ArCH}_{2} \mathrm{Ar},{ }^{2} J=13.2 \mathrm{~Hz}$ ), 4.35 and 3.52 (AB spin system, $2 \mathrm{H}, \mathrm{ArCH}_{2} \mathrm{Ar},{ }^{2} J=13.6$ $\mathrm{Hz}), 4.05\left(\mathrm{t}, 2 \mathrm{H}, \mathrm{OCH}_{2},{ }^{3} \mathrm{~J}=8.4 \mathrm{~Hz}\right), 4.02\left(\mathrm{t}, 2 \mathrm{H}, \mathrm{OCH}_{2},{ }^{3} \mathrm{~J}=8.8 \mathrm{~Hz}\right), 3.76\left(\mathrm{t}, 2 \mathrm{H}, \mathrm{OCH}_{2},{ }^{3} J=\right.$ $6.6 \mathrm{~Hz}), 3.71-3.61\left(\mathrm{~m}, 2 \mathrm{H}, \mathrm{OCH}_{2}\right), 2.02-1.81\left(\mathrm{~m}, 8 \mathrm{H}, \mathrm{CH}_{2} \mathrm{CH}_{3}\right), 1.20-0.77\left(\mathrm{~m}, 3 \mathrm{H}, \mathrm{P}\left(\mathrm{BH}_{3}\right)\right)$, $1.13\left(\mathrm{t}, 3 \mathrm{H}, \mathrm{CH}_{2} \mathrm{CH}_{3},{ }^{3} \mathrm{~J}=7.6 \mathrm{~Hz}\right), 1.05$ (t, 3H, $\left.\mathrm{CH}_{2} \mathrm{CH}_{3},{ }^{3} \mathrm{~J}=7.6 \mathrm{~Hz}\right), 0.92$ (t, 6H, $\mathrm{CH}_{2} \mathrm{CH}_{3}$, $\left.{ }^{3} J=7.5 \mathrm{~Hz}\right) ;{ }^{13} \mathrm{C}\left\{{ }^{1} \mathrm{H}\right\}$ NMR $\left(\mathrm{CDCl}_{3}, 101 \mathrm{MHz}\right): \delta=157.98$ (s, arom Cq-O), 157.80 (d, arom 
$\left.\mathrm{Cq}-\mathrm{O},{ }^{3} J(\mathrm{CP})=5.9 \mathrm{~Hz}\right), 155.53(\mathrm{~s}$, arom Cq-O), 155.21 (s, arom Cq-O), 144.08-120.88 (arom. C's), $77.09\left(\mathrm{~s}, \mathrm{OCH}_{2}\right), 76.97\left(\mathrm{~s}, \mathrm{OCH}_{2}\right), 76.91\left(\mathrm{~s}, \mathrm{OCH}_{2}\right), 76.61\left(\mathrm{~s}, \mathrm{OCH}_{2}\right), 31.58$ (s, $\mathrm{ArCH} \mathrm{H}_{2} \mathrm{Ar}$ ), 31.19 (s, $\left.\mathrm{ArCH} \mathrm{H}_{2} \mathrm{Ar}\right), 30.30$ (d, $\left.\mathrm{ArCH} \mathrm{H}_{2} \mathrm{Ar},{ }^{3} \mathrm{~J}(\mathrm{CP})=8.1 \mathrm{~Hz}\right), 23.68\left(\mathrm{CH}_{2} \mathrm{CH}_{3}\right)$, $23.53\left(\mathrm{CH}_{2} \mathrm{CH}_{3}\right), 23.24\left(\mathrm{CH}_{2} \mathrm{CH}_{3}\right), 23.17\left(\mathrm{CH}_{2} \mathrm{CH}_{3}\right), 10.95\left(\mathrm{CH}_{2} \mathrm{CH}_{3}\right), 10.78\left(\mathrm{CH}_{2} \mathrm{CH}_{3}\right)$, $10.14\left(\mathrm{CH}_{2} \mathrm{CH}_{3}\right), 10.06\left(\mathrm{CH}_{2} \mathrm{CH}_{3}\right) ;{ }^{31} \mathrm{P}\left\{{ }^{1} \mathrm{H}\right\} \mathrm{NMR}\left(\mathrm{CDCl}_{3}, 162 \mathrm{MHz}\right): \delta=-11.5(\mathrm{~s}, \mathrm{PPh})$ ppm; MS (ESI): $m / z=797.37[\mathrm{M}+\mathrm{Na}]^{+}$expected isotopic profiles; elemental analysis calcd (\%) for $\mathrm{C}_{52} \mathrm{H}_{55} \mathrm{O}_{4} \mathrm{P}(\mathrm{Mr}=774.97)$ : C 80.59, H 7.15; found (\%): C 80.72, H 7.32.

Phosphole oxide 9: To a solution of phosphole $8(0.050 \mathrm{~g}, 0.06 \mathrm{mmol})$ in $\mathrm{CH}_{2} \mathrm{Cl}_{2}(10 \mathrm{~mL})$ was added dropwise $\mathrm{H}_{2} \mathrm{O}_{2}(30 \%$ in water, $2.00 \mathrm{ml}, 2.50 \mathrm{mmol})$. The solution was stirred at room temperature for $1 \mathrm{~h}$, then treated with a mixture of $\mathrm{CH}_{2} \mathrm{Cl}_{2}(10 \mathrm{~mL})$ and water $(20 \mathrm{~mL})$. The aqueous layer was separated and washed with $\mathrm{CH}_{2} \mathrm{Cl}_{2}(2 \times 10 \mathrm{~mL})$. The organic phases were combined and washed with water $(2 \times 10 \mathrm{~mL})$. After drying over $\mathrm{Na}_{2} \mathrm{SO}_{4}$, the solution was filtered through a glass frit before being evaporated to dryness to afford phosphole oxide 9 as a white solid $(0.050 \mathrm{~g}$, yield $98 \%) .{ }^{1} \mathrm{H}$ NMR $\left(\mathrm{CDCl}_{3}, 500 \mathrm{MHz}\right): \delta=7.81-7.73(\mathrm{~m}, 3 \mathrm{H}$, arom. $\mathrm{CH}, \mathrm{C}_{6} \mathrm{H}_{4}$ and $\left.\mathrm{P}(\mathrm{O}) \mathrm{Ph}\right), 7.66\left(\mathrm{t}, 1 \mathrm{H}\right.$, arom. $\left.\mathrm{CH}, \mathrm{C}_{6} \mathrm{H}_{4},{ }^{3} \mathrm{~J}=8.5 \mathrm{~Hz}\right), 7.62(\mathrm{~d}, 1 \mathrm{H}$, arom. $\mathrm{CH}$, calixarene, $\left.{ }^{4} J(\mathrm{PH})=4.0 \mathrm{~Hz}\right), 7.55\left(\mathrm{t}, 1 \mathrm{H}\right.$, arom. $\left.\mathrm{CH}, \mathrm{C}_{6} \mathrm{H}_{4},{ }^{3} J=8.0 \mathrm{~Hz}\right), 7.53(\mathrm{t}, 1 \mathrm{H}$, arom. $\left.\mathrm{CH}, \mathrm{P}(\mathrm{O}) \mathrm{Ph},{ }^{3} J=8.0 \mathrm{~Hz}\right), 7.44\left(\mathrm{dt}, 2 \mathrm{H}\right.$, arom. $\mathrm{CH}, \mathrm{P}(\mathrm{O}) \mathrm{Ph},{ }^{3} J=7.5 \mathrm{~Hz},{ }^{4} J(\mathrm{PH})=3.0$ $\mathrm{Hz}$ ), $7.30\left(\mathrm{dt}, 1 \mathrm{H}\right.$, arom. $\left.\mathrm{CH}, \mathrm{C}_{6} \mathrm{H}_{4},{ }^{3} J=7.5 \mathrm{~Hz},{ }^{4} \mathrm{~J}(\mathrm{PH})=3.5 \mathrm{~Hz}\right), 7.14$ (d, 2H, arom. $\mathrm{CH}$, calixarene, $\left.{ }^{3} J=7.0 \mathrm{~Hz}\right), 6.94\left(\mathrm{t}, 1 \mathrm{H}\right.$, arom. $\mathrm{CH}$, calixarene, $\left.{ }^{3} \mathrm{~J}=7.2 \mathrm{~Hz}\right), 6.71(\mathrm{~d}, 1 \mathrm{H}$, arom. $\mathrm{CH}$, calixarene, $\left.{ }^{3} J=7.5 \mathrm{~Hz}\right), 6.27\left(\mathrm{t}, 1 \mathrm{H}\right.$, arom. $\mathrm{CH}$, calixarene, $\left.{ }^{3} J=7.5 \mathrm{~Hz}\right), 6.22(\mathrm{t}, 1 \mathrm{H}$, arom. $\mathrm{CH}$, calixarene, ${ }^{3} \mathrm{~J}=7.5 \mathrm{~Hz}$ ), 6.14-6.07 (m, 3H, arom. $\mathrm{CH}$, calixarene), 4.55 and 3.29 (AB spin system, $2 \mathrm{H}, \mathrm{ArCH}_{2} \mathrm{Ar},{ }^{2} \mathrm{~J}=13.0 \mathrm{~Hz}$ ), 4.44 and 3.16 (AB spin system, $2 \mathrm{H}, \mathrm{ArCH}_{2} \mathrm{Ar}$, ${ }^{2} J=13.0 \mathrm{~Hz}$ ), 4.41 and 3.14 (AB spin system, $\left.2 \mathrm{H}, \mathrm{ArCH}_{2} \mathrm{Ar},{ }^{2} J=13.5 \mathrm{~Hz}\right), 4.16$ and 3.60 (AB spin system, 2H, $\left.\mathrm{ArCH}_{2} \mathrm{Ar},{ }^{2} J=13.0 \mathrm{~Hz}\right), 4.11-4.05\left(\mathrm{~m}, 1 \mathrm{H}, \mathrm{OCH}_{2}\right), 4.04-3.98(\mathrm{~m}, 3 \mathrm{H}$, $\left.\mathrm{OCH}_{2}\right), 3.71-3.66\left(\mathrm{~m}, 2 \mathrm{H}, \mathrm{OCH}_{2}\right), 3.58-3.53\left(\mathrm{~m}, 2 \mathrm{H}, \mathrm{OCH}_{2}\right), 2.00-1.87\left(\mathrm{~m}, 6 \mathrm{H}, \mathrm{CH}_{2} \mathrm{CH}_{3}\right)$, 1.82-1.75 (m, $\left.2 \mathrm{H}, \mathrm{CH}_{2} \mathrm{CH}_{3}\right), 1.12\left(\mathrm{t}, 3 \mathrm{H}, \mathrm{CH}_{2} \mathrm{CH}_{3},{ }^{3} \mathrm{~J}=7.5 \mathrm{~Hz}\right), 1.01$ (t, $3 \mathrm{H}, \mathrm{CH}_{2} \mathrm{CH}_{3},{ }^{3} \mathrm{~J}=7.5$ $\mathrm{Hz}), 0.88$ (t, $\left.3 \mathrm{H}, \mathrm{CH}_{2} \mathrm{CH}_{3},{ }^{3} \mathrm{~J}=7.5 \mathrm{~Hz}\right), 0.86\left(\mathrm{t}, 3 \mathrm{H}, \mathrm{CH}_{2} \mathrm{CH}_{3},{ }^{3} \mathrm{~J}=7.5 \mathrm{~Hz}\right) ;{ }^{13} \mathrm{C}\left\{{ }^{1} \mathrm{H}\right\} \mathrm{NMR}$ $\left(\mathrm{CDCl}_{3}, 101 \mathrm{MHz}\right): \delta=160.10\left(\mathrm{~d}\right.$, arom Cq-O, $\left.{ }^{3} \mathrm{~J}(\mathrm{CP})=10.4 \mathrm{~Hz}\right), 158.11(\mathrm{~s}$, arom Cq-O$)$, 155.11 (s, arom Cq-O), 15507 (s, arom Cq-O), 142.98-120.58 (arom. C's), 77.13 (s, $\mathrm{OCH}_{2}$ ), $76.92\left(\mathrm{~s}, \mathrm{OCH}_{2}\right), 76.88\left(\mathrm{~s}, \mathrm{OCH}_{2}\right), 76.62\left(\mathrm{~s}, \mathrm{OCH}_{2}\right), 31.61\left(\mathrm{~s}, \mathrm{ArCH} \mathrm{H}_{2} \mathrm{Ar}\right), 31.16\left(\mathrm{~s}, \mathrm{ArCH} \mathrm{H}_{2} \mathrm{Ar}\right)$, $30.98(\mathrm{~s}, \mathrm{ArCH} 2 \mathrm{Ar}), 28.55\left(\mathrm{~d}, \mathrm{ArCH} \mathrm{Ar}_{2}{ }^{3} \mathrm{~J}(\mathrm{CP})=3.1 \mathrm{~Hz}\right), 23.68\left(\mathrm{CH}_{2} \mathrm{CH}_{3}\right), 23.58\left(\mathrm{CH}_{2} \mathrm{CH}_{3}\right)$, $23.18\left(\mathrm{CH}_{2} \mathrm{CH}_{3}\right), 23.09\left(\mathrm{CH}_{2} \mathrm{CH}_{3}\right), 11.01\left(\mathrm{CH}_{2} \mathrm{CH}_{3}\right), 10.86\left(\mathrm{CH}_{2} \mathrm{CH}_{3}\right), 9.93\left(\mathrm{CH}_{2} \mathrm{CH}_{3}\right)$; ${ }^{31} \mathrm{P}\left\{{ }^{1} \mathrm{H}\right\} \mathrm{NMR}\left(\mathrm{CDCl}_{3}, 162 \mathrm{MHz}\right): \delta=33.4(\mathrm{~s}, \mathrm{P}(\mathrm{O}) \mathrm{Ph}) \mathrm{ppm}$; elemental analysis calcd (\%) for $\mathrm{C}_{52} \mathrm{H}_{55} \mathrm{O}_{5} \mathrm{P}(\mathrm{Mr}=790.97)$ : C 78.96, H 7.01; found (\%): C 79.04, H 7.11.

Palladium complex 10: A solution of $[\mathrm{Pd}(8-\mathrm{mq}) \mathrm{Cl}]_{2}(0.018 \mathrm{~g}, 0.03 \mathrm{mmol})$ in $\mathrm{CH}_{2} \mathrm{Cl}_{2}(10$ $\mathrm{mL})$ was added to a stirred solution of $8(0.049 \mathrm{~g}, 0.06 \mathrm{mmol})$ in $\mathrm{CH}_{2} \mathrm{Cl}_{2}(10 \mathrm{~mL})$. After stirring at room temperature for $0.5 \mathrm{~h}$, the reaction mixture was concentrated to about $2 \mathrm{~mL}$ and $n$-hexane $(20 \mathrm{~mL})$ was added. The yellow precipitate formed was separated by filtration and dried under vacuum $(0.050 \mathrm{~g}$, yield $73 \%)$. ${ }^{1} \mathrm{H} \mathrm{NMR}\left(\mathrm{CDCl}_{3}, 500 \mathrm{MHz}\right): \delta=9.53(\mathrm{tt}, 1 \mathrm{H}$, arom. CH of $\left.8-\mathrm{mq},{ }^{3} J=3.5 \mathrm{~Hz},{ }^{5} J=1.0 \mathrm{~Hz}\right), 8.14\left(\mathrm{dd}, 1 \mathrm{H}\right.$, arom. $\mathrm{CH}$ of $8-\mathrm{mq},{ }^{3} J=8.5 \mathrm{~Hz},{ }^{4} J$ $=1.0 \mathrm{~Hz}), 7.90\left(\mathrm{t}, 1 \mathrm{H}\right.$, arom. $\left.\mathrm{CH}, \mathrm{C}_{6} \mathrm{H}_{4},{ }^{3} \mathrm{~J}=8.2 \mathrm{~Hz}\right), 7.86-7.80(\mathrm{~m}, 3 \mathrm{H}$, arom. $\mathrm{CH}, \mathrm{PPh}$ and 
Pd-8-mq), 7.77 (d, 1H, arom. CH, calixarene, $\left.{ }^{4} J(\mathrm{PH})=2.0 \mathrm{~Hz}\right), 7.52-7.47$ (m, 2H, arom. CH, $\mathrm{PPh}$ ), 7.38-7.32 (m, 6H, arom. $\mathrm{CH}, \mathrm{C}_{6} \mathrm{H}_{4}$ and $\mathrm{CH}$ of 8-mq), 7.26-7.24 (m, 1H, arom. $\mathrm{CH}$ of 8$\mathrm{mq}), 7.09$ (dd, $1 \mathrm{H}$, arom. CH, calixarene, $\left.{ }^{3} \mathrm{~J}=7.5 \mathrm{~Hz},{ }^{4} \mathrm{~J}=1.5 \mathrm{~Hz}\right), 7.02(\mathrm{dd}, 1 \mathrm{H}$, arom. $\mathrm{CH}$, calixarene, $\left.{ }^{3} J=7.5 \mathrm{~Hz},{ }^{4} J=1.5 \mathrm{~Hz}\right), 6.87\left(\mathrm{t}, 1 \mathrm{H}\right.$, arom. $\mathrm{CH}$, calixarene, $\left.{ }^{3} J=7.5 \mathrm{~Hz}\right), 6.75(\mathrm{~d}$, $1 \mathrm{H}$, arom. $\mathrm{CH}$, calixarene, $\left.{ }^{3} \mathrm{~J}=7.5 \mathrm{~Hz}\right), 6.14-6.13(\mathrm{~m}, 2 \mathrm{H}$, arom. $\mathrm{CH}$, calixarene), 6.02-6.01 (m, 1H, arom. $\mathrm{CH}$, calixarene), $5.63\left(\mathrm{~d}, 1 \mathrm{H}\right.$, arom. $\mathrm{CH}$, calixarene, $\left.{ }^{3} J=7.5 \mathrm{~Hz}\right), 4.99(\mathrm{t}, 1 \mathrm{H}$, arom. $\mathrm{CH}$, calixarene, ${ }^{3} \mathrm{~J}=7.5 \mathrm{~Hz}$ ), 4.60 and 3.35 (AB spin system, $2 \mathrm{H}, \mathrm{ArCH} \mathrm{H}_{2} \mathrm{Ar},{ }^{2} J=13.5$ $\mathrm{Hz}$ ), 4.52 and 4.35 (AB spin system, $2 \mathrm{H}, \mathrm{ArCH}_{2} \mathrm{Ar},{ }^{2} J=14.0 \mathrm{~Hz}$ ), 4.43 and 3.13 (AB spin system, $2 \mathrm{H}, \mathrm{ArCH} \mathrm{H}_{2} \mathrm{Ar},{ }^{2} J=13.5 \mathrm{~Hz}$ ), 4.33 and 2.98 (AB spin system, $2 \mathrm{H}, \mathrm{ArCH}_{2} \mathrm{Ar},{ }^{2} J=13.5$ $\mathrm{Hz}), 4.18-4.08\left(\mathrm{~m}, 2 \mathrm{H}, \mathrm{OCH}_{2}\right), 4.03-3.93\left(\mathrm{~m}, 2 \mathrm{H}, \mathrm{OCH}_{2}\right), 3.73-3.66\left(\mathrm{~m}, 2 \mathrm{H}, \mathrm{OCH}_{2}\right), 3.63-$ $3.59\left(\mathrm{~m}, 1 \mathrm{H}, \mathrm{OCH}_{2}\right), 3.48-3.44\left(\mathrm{~m}, 1 \mathrm{H}, \mathrm{OCH}_{2}\right), 3.12$ and $2.42(\mathrm{ABX}$ spin system with $\mathrm{X}=\mathrm{P}$, $\left.2 \mathrm{H}, \mathrm{CH}_{2} \mathrm{Pd},{ }^{2} J(\mathrm{AB})=14.5 \mathrm{~Hz},{ }^{3} J(\mathrm{AX})=0 \mathrm{~Hz},{ }^{3} J(\mathrm{BX})=7.5 \mathrm{~Hz}\right), 2.02-1.85\left(\mathrm{~m}, 6 \mathrm{H}, \mathrm{CH}_{2} \mathrm{CH}_{3}\right)$, 1.80-1.73 (m, 2H, $\left.\mathrm{CH}_{2} \mathrm{CH}_{3}\right), 1.13$ (t, 3H, $\left.\mathrm{CH}_{2} \mathrm{CH}_{3},{ }^{3} \mathrm{~J}=7.2 \mathrm{~Hz}\right), 1.02$ (t, $3 \mathrm{H}, \mathrm{CH}_{2} \mathrm{CH}_{3},{ }^{3} \mathrm{~J}=7.5$ $\mathrm{Hz}), 0.89\left(\mathrm{t}, 3 \mathrm{H}, \mathrm{CH}_{2} \mathrm{CH}_{3},{ }^{3} \mathrm{~J}=7.7 \mathrm{~Hz}\right), 0.85\left(\mathrm{t}, 3 \mathrm{H}, \mathrm{CH}_{2} \mathrm{CH}_{3},{ }^{3} J=7.5 \mathrm{~Hz}\right) ;{ }^{13} \mathrm{C}\left\{{ }^{1} \mathrm{H}\right\} \mathrm{NMR}$ $\left(\mathrm{CDCl}_{3}, 125 \mathrm{MHz}\right): \delta=159.74\left(\mathrm{~d}\right.$, arom Cq-O, $\left.{ }^{3} J(\mathrm{CP})=11.1 \mathrm{~Hz}\right), 158.33$ (s, arom Cq-O), 155.27 (s, arom Cq-O), 154.80 (s, arom Cq-O), 152.07-120.73 (arom. C's), 77.03 (s, $\mathrm{OCH}_{2}$ ), $76.90\left(\mathrm{~s}, \mathrm{OCH}_{2}\right), 76.85\left(\mathrm{~s}, \mathrm{OCH}_{2}\right), 76.71\left(\mathrm{~s}, \mathrm{OCH}_{2}\right), 33.14\left(\mathrm{~d}, \mathrm{Pd}_{-} \mathrm{CH}_{2},{ }^{2} J(\mathrm{CP})=3.0 \mathrm{~Hz}\right)$, 31.82 (s, $\left.\mathrm{ArCH} \mathrm{H}_{2} \mathrm{Ar}\right), 31.15$ (s, $\left.\mathrm{ArCH} \mathrm{H}_{2} \mathrm{Ar}\right), 30.92$ (s, $\left.\mathrm{ArCH} \mathrm{H}_{2} \mathrm{Ar}\right), 30.58\left(\mathrm{~d}, \mathrm{ArCH}_{2} \mathrm{Ar},{ }^{3} J(\mathrm{CP})=\right.$ $6.5 \mathrm{~Hz}), 23.71\left(\mathrm{CH}_{2} \mathrm{CH}_{3}\right), 23.68\left(\mathrm{CH}_{2} \mathrm{CH}_{3}\right), 23.14\left(\mathrm{CH}_{2} \mathrm{CH}_{3}\right), 23.07\left(\mathrm{CH}_{2} \mathrm{CH}_{3}\right), 11.05$ $\left(\mathrm{CH}_{2} \mathrm{CH}_{3}\right), 10.91\left(\mathrm{CH}_{2} \mathrm{CH}_{3}\right), 10.10\left(\mathrm{CH}_{2} \mathrm{CH}_{3}\right), 9.95\left(\mathrm{CH}_{2} \mathrm{CH}_{3}\right) ;{ }^{31} \mathrm{P}\left\{{ }^{1} \mathrm{H}\right\} \mathrm{NMR}\left(\mathrm{CDCl}_{3}, 162\right.$ $\mathrm{MHz}): \delta=25.73(\mathrm{~s}, \mathrm{PPh}) \mathrm{ppm}$; MS (ESI): $m / z=1022.3564[\mathrm{M}-\mathrm{Cl}]^{+}$expected isotopic profile.

Gold complex 11: A solution of [ $\mathrm{AuCl}(\mathrm{THT})](0.041 \mathrm{~g}, 0.13 \mathrm{mmol})$ in $\mathrm{CH}_{2} \mathrm{Cl}_{2}(25 \mathrm{~mL})$ was added to a stirred solution of benzophosphole $8(0.100 \mathrm{~g}, 0.13 \mathrm{mmol})$ in $\mathrm{CH}_{2} \mathrm{Cl}_{2}(25 \mathrm{~mL})$. After stirring at room temperature for $0.5 \mathrm{~h}$, the reaction mixture was concentrated to about 2 $\mathrm{mL}$ and then $n$-hexane $(20 \mathrm{~mL})$ was added. A white precipitate formed, which was then separated by filtration and dried under vacuum to give complex $11(0.123 \mathrm{~g}$, yield $95 \%) .{ }^{1} \mathrm{H}$ NMR $\left(\mathrm{CDCl}_{3}, 500 \mathrm{MHz}\right): \delta=7.89\left(\mathrm{~d}, 1 \mathrm{H}\right.$, arom. $\left.\mathrm{CH}, \mathrm{C}_{6} \mathrm{H}_{4},{ }^{3} J=6.0 \mathrm{~Hz}\right), 7.76(\mathrm{~d}, 1 \mathrm{H}$, arom. $\mathrm{CH}$, calixarene, $\left.{ }^{4} J(\mathrm{PH})=3.0 \mathrm{~Hz}\right), 7.66-7.61\left(\mathrm{~m}, 3 \mathrm{H}\right.$, arom. $\mathrm{CH}, \mathrm{C}_{6} \mathrm{H}_{4}$ and $\left.\mathrm{PPh}\right), 7.58(\mathrm{t}, 1 \mathrm{H}$, arom. $\left.\mathrm{CH}, \mathrm{PPh},{ }^{3} J=7.7 \mathrm{~Hz}\right), 7.54\left(\mathrm{~m}, 1 \mathrm{H}\right.$, arom. $\left.\mathrm{CH}, \mathrm{C}_{6} \mathrm{H}_{4}\right), 7.43$ (dt, 2H, arom. $\mathrm{CH}, \mathrm{PPh},{ }^{3} J$ $\left.=7.7 \mathrm{~Hz},{ }^{4} J(\mathrm{PH})=2.0 \mathrm{~Hz}\right), 7.35\left(\mathrm{dt}, 1 \mathrm{H}\right.$, arom. $\left.\mathrm{CH}, \mathrm{C}_{6} \mathrm{H}_{4},{ }^{3} \mathrm{~J}=7.2 \mathrm{~Hz},{ }^{4} J(\mathrm{PH})=3.5 \mathrm{~Hz}\right), 7.14$ (d, $1 \mathrm{H}$, arom. $\mathrm{CH}$, calixarene, $\left.{ }^{3} J=7.0 \mathrm{~Hz}\right), 7.12\left(\mathrm{~d}, 1 \mathrm{H}\right.$, arom. $\mathrm{CH}$, calixarene, $\left.{ }^{3} J=7.0 \mathrm{~Hz}\right)$, $6.93\left(\mathrm{t}, 1 \mathrm{H}\right.$, arom. $\mathrm{CH}$, calixarene, $\left.{ }^{3} J=7.5 \mathrm{~Hz}\right), 6.70\left(\mathrm{~d}, 1 \mathrm{H}\right.$, arom. $\mathrm{CH}$, calixarene, ${ }^{3} J=7.0$ $\mathrm{Hz}), 6.26\left(\mathrm{t}, 1 \mathrm{H}\right.$, arom. $\mathrm{CH}$, calixarene, $\left.{ }^{3} \mathrm{~J}=7.5 \mathrm{~Hz}\right), 6.25\left(\mathrm{t}, 1 \mathrm{H}\right.$, arom. $\mathrm{CH}$, calixarene, ${ }^{3} J=$ $7.5 \mathrm{~Hz}), 6.14\left(\mathrm{~d}, 1 \mathrm{H}\right.$, arom. $\mathrm{CH}$, calixarene, $\left.{ }^{3} \mathrm{~J}=6.2 \mathrm{~Hz}\right), 6.12(\mathrm{~d}, 1 \mathrm{H}$, arom. $\mathrm{CH}$, calixarene, ${ }^{3} J=6.2 \mathrm{~Hz}$ ), 6.08 (d, 1H, arom. CH, calixarene, ${ }^{3} J=7.5 \mathrm{~Hz}$ ), 4.58 and 3.35 (AB spin system, $2 \mathrm{H}, \mathrm{ArCH}_{2} \mathrm{Ar},{ }^{2} \mathrm{~J}=14.0 \mathrm{~Hz}$ ), 4.45 and 3.17 (AB spin system, $2 \mathrm{H}, \mathrm{ArCH}_{2} \mathrm{Ar},{ }^{2} J=13.0 \mathrm{~Hz}$ ), 4.40 and 3.15 (AB spin system, $2 \mathrm{H}, \mathrm{ArCH}_{2} \mathrm{Ar},{ }^{2} J=13.5 \mathrm{~Hz}$ ), 4.23 and 3.66 (AB spin system, $\left.2 \mathrm{H}, \mathrm{ArCH}_{2} \mathrm{Ar},{ }^{2} \mathrm{~J}=14.0 \mathrm{~Hz}\right), 4.11-4.02\left(\mathrm{~m}, 2 \mathrm{H}, \mathrm{OCH}_{2}\right), 4.00\left(\mathrm{t}, 2 \mathrm{H}, \mathrm{OCH}_{2},{ }^{3} \mathrm{~J}=8.2 \mathrm{~Hz}\right), 3.74-$ $3.67\left(\mathrm{~m}, 2 \mathrm{H}, \mathrm{OCH}_{2}\right), 3.60\left(\mathrm{t}, 2 \mathrm{H}, \mathrm{OCH}_{2},{ }^{3} \mathrm{~J}=6.7 \mathrm{~Hz}\right), 1.99-1.85\left(\mathrm{~m}, 6 \mathrm{H}, \mathrm{CH}_{2} \mathrm{CH}_{3}\right), 1.82-1.75$ (m, 2H, $\left.\mathrm{CH}_{2} \mathrm{CH}_{3}\right), 1.12\left(\mathrm{t}, 3 \mathrm{H}, \mathrm{CH}_{2} \mathrm{CH}_{3},{ }^{3} \mathrm{~J}=7.5 \mathrm{~Hz}\right.$ ), 1.03 (t, $3 \mathrm{H}, \mathrm{CH}_{2} \mathrm{CH}_{3},{ }^{3} \mathrm{~J}=7.2 \mathrm{~Hz}$ ), 0.87 (t, $\left.\left.3 \mathrm{H}, \mathrm{CH}_{2} \mathrm{CH}_{3},{ }^{3} \mathrm{~J}=7.5 \mathrm{~Hz}\right), 0.84 \mathrm{t}, 3 \mathrm{H}, \mathrm{CH}_{2} \mathrm{CH}_{3},{ }^{3} \mathrm{~J}=7.5 \mathrm{~Hz}\right) ;{ }^{13} \mathrm{C}\left\{{ }^{1} \mathrm{H}\right\} \mathrm{NMR}\left(\mathrm{CDCl}_{3}, 125\right.$ 
MHz): $\delta=157.95\left(\mathrm{~d}\right.$, arom Cq-O, $\left.{ }^{3} J(\mathrm{CP})=11.7 \mathrm{~Hz}\right), 157.15(\mathrm{~s}$, arom Cq-O), 154.21 (s, arom Cq-O), 153.73 (s, arom Cq-O), 142.41-120.37 (arom. C's), 76.09 (s, $\left.\mathrm{OCH}_{2}\right), 75.92$ (s, $\mathrm{OCH}_{2}$ ), $75.89\left(\mathrm{~s}, \mathrm{OCH}_{2}\right), 75.71\left(\mathrm{~s}, \mathrm{OCH}_{2}\right), 30.75\left(\mathrm{~s}, \mathrm{ArCH} \mathrm{H}_{2} \mathrm{Ar}\right), 30.12\left(\mathrm{~s}, \mathrm{ArCH} \mathrm{Hr}_{2} \mathrm{Ar}, 30.05\right.$ (s, $\left.\mathrm{ArCH} \mathrm{H}_{2} \mathrm{Ar}\right), 28.71\left(\mathrm{~d}, \mathrm{ArCH} \mathrm{Hr}_{2} \mathrm{~A} J(\mathrm{CP})=7.1 \mathrm{~Hz}\right), 22.66\left(\mathrm{CH}_{2} \mathrm{CH}_{3}\right), 22.56\left(\mathrm{CH}_{2} \mathrm{CH}_{3}\right), 22.12$ $\left(\mathrm{CH}_{2} \mathrm{CH}_{3}\right), 22.07\left(\mathrm{CH}_{2} \mathrm{CH}_{3}\right), 10.00\left(\mathrm{CH}_{2} \mathrm{CH}_{3}\right), 9.84\left(\mathrm{CH}_{2} \mathrm{CH}_{3}\right), 8.95\left(\mathrm{CH}_{2} \mathrm{CH}_{3}\right), 8.92$ $\left(\mathrm{CH}_{2} \mathrm{CH}_{3}\right) ;{ }^{31} \mathrm{P}\left\{{ }^{1} \mathrm{H}\right\} \mathrm{NMR}\left(\mathrm{CDCl}_{3}, 162 \mathrm{MHz}\right): \delta=-22.8$ (s, PPh) ppm; MS (ESI): $\mathrm{m} / z=$ $1029.31[\mathrm{M}+\mathrm{Na}]^{+}$expected isotopic profile; elemental analysis calcd (\%) for $\mathrm{C}_{52} \mathrm{H}_{55} \mathrm{AuClO}_{4} \mathrm{P}(\mathrm{Mr}=1007.39): \mathrm{C} 62.00, \mathrm{H}$ 5.50; found (\%): C 62.05, H 5.53.

Rhodium complex 12: A solution of $\left[\mathrm{Rh}(\mathrm{acac})(\mathrm{CO})_{2}\right](0.040 \mathrm{~g}, 0.15 \mathrm{mmol})$ in $\mathrm{CH}_{2} \mathrm{Cl}_{2}(15$ $\mathrm{mL})$ was added to a stirred solution of benzophosphole $8(0.120 \mathrm{~g}, 0.15 \mathrm{mmol})$ in $\mathrm{CH}_{2} \mathrm{Cl}_{2}(15$ $\mathrm{mL}$ ). After stirring at room temperature for $0.5 \mathrm{~h}$, the solution was concentrated to about $2 \mathrm{~mL}$ and $\mathrm{MeOH}(5 \mathrm{~mL})$ was added. A yellow precipitate formed, which was separated by filtration then dried under vacuum $(0.081 \mathrm{~g}$, yield $52 \%) .{ }^{1} \mathrm{H}$ NMR $\left(\mathrm{C}_{6} \mathrm{D}_{6}, 500 \mathrm{MHz}\right): \delta=8.00-7.95(\mathrm{~m}$, $2 \mathrm{H}$, arom. $\mathrm{CH}, \mathrm{PPh}), 7.81\left(\mathrm{t}, 1 \mathrm{H}\right.$, arom. $\left.\mathrm{CH}, \mathrm{C}_{6} \mathrm{H}_{4},{ }^{3} \mathrm{~J}=8.0 \mathrm{~Hz}\right), 7.71(\mathrm{~d}, 1 \mathrm{H}$, arom. $\mathrm{CH}$, calixarene, $\left.{ }^{3} \mathrm{~J}=7.5 \mathrm{~Hz}\right), 7.68\left(\mathrm{~d}, 1 \mathrm{H}\right.$, arom. $\mathrm{CH}$, calixarene, $\left.{ }^{4} \mathrm{~J}(\mathrm{PH})=1.5 \mathrm{~Hz}\right), 7.62(\mathrm{~d}, 1 \mathrm{H}$, arom. $\mathrm{CH}$, calixarene, $\left.{ }^{3} \mathrm{~J}=7.5 \mathrm{~Hz}\right), 7.20-7.16(\mathrm{~m}, 1 \mathrm{H}$, arom. $\mathrm{CH}$, calixarene), 7.16-7.11 (m, $1 \mathrm{H}$, arom. $\left.\mathrm{CH}, \mathrm{C}_{6} \mathrm{H}_{4}\right), 7.07\left(\mathrm{dd}, 1 \mathrm{H}\right.$, arom. $\left.\mathrm{CH}, \mathrm{C}_{6} \mathrm{H}_{4},{ }^{3} J=7.5 \mathrm{~Hz},{ }^{4} J(\mathrm{PH})=1.5 \mathrm{~Hz}\right), 7.01-6.96$ (m, $4 \mathrm{H}$, arom. $\mathrm{CH}$ of $\mathrm{PPh}$, calixarene and $\left.\mathrm{C}_{6} \mathrm{H}_{4}\right), 6.92\left(\mathrm{td}, 1 \mathrm{H}\right.$, arom. $\mathrm{CH}, \mathrm{PPh},{ }^{3} J=7.0 \mathrm{~Hz}$, $\left.{ }^{5} J(\mathrm{PH})=1.0 \mathrm{~Hz}\right), 6.47\left(\mathrm{t}, 1 \mathrm{H}\right.$, arom. $\mathrm{CH}$, calixarene, $\left.{ }^{3} J=7.7 \mathrm{~Hz}\right), 6.35-6.30(\mathrm{~m}, 2 \mathrm{H}$, arom. $\mathrm{CH}$, calixarene), $6.26\left(\mathrm{~d}, 2 \mathrm{H}\right.$, arom. $\mathrm{CH}$, calixarene, $\left.{ }^{3} \mathrm{~J}=7.5 \mathrm{~Hz}\right), 5.17$ (s, CH, acac), 4.77 and 4.55 (AB spin system, $2 \mathrm{H}, \mathrm{ArCH}_{2} \mathrm{Ar},{ }^{2} J=13.5 \mathrm{~Hz}$ ), 4.67 and 3.31 (AB spin system, $2 \mathrm{H}$, $\mathrm{ArCH}_{2} \mathrm{Ar},{ }^{2} \mathrm{~J}=13.7 \mathrm{~Hz}$ ), 4.55 and 3.17 (AB spin system, $2 \mathrm{H}, \mathrm{ArCH}_{2} \mathrm{Ar},{ }^{2} J=13.5 \mathrm{~Hz}$ ), 4.52 and $3.12\left(\mathrm{AB}\right.$ spin system, $\left.2 \mathrm{H}, \mathrm{ArCH}_{2} \mathrm{Ar},{ }^{2} \mathrm{~J}=13.5 \mathrm{~Hz}\right), 4.34-4.24\left(\mathrm{~m}, 2 \mathrm{H}, \mathrm{OCH}_{2}\right), 4.15-4.05$ $\left(\mathrm{m}, 2 \mathrm{H}, \mathrm{OCH}_{2}\right), 3.64-3.57\left(\mathrm{~m}, 2 \mathrm{H}, \mathrm{OCH}_{2}\right), 3.52-3.44\left(\mathrm{~m}, 2 \mathrm{H}, \mathrm{OCH}_{2}\right), 2.19-2.10(\mathrm{~m}, 2 \mathrm{H}$, $\left.\mathrm{CH}_{2} \mathrm{CH}_{3}\right), 2.05-1.97\left(\mathrm{~m}, 2 \mathrm{H}, \mathrm{CH}_{2} \mathrm{CH}_{3}\right), 1.81-1.72\left(\mathrm{~m}, 2 \mathrm{H}, \mathrm{CH}_{2} \mathrm{CH}_{3}\right), 1.76$ (s, $3 \mathrm{H}, \mathrm{CH}_{3}$, acac), 1.54-1.56 (m, 2H, $\left.\mathrm{CH}_{2} \mathrm{CH}_{3}\right), 1.51$ (s, $\left.3 \mathrm{H}, \mathrm{CH}_{3}, \mathrm{acac}\right), 1.02$ (t, $3 \mathrm{H}, \mathrm{CH}_{2} \mathrm{CH}_{3},{ }^{3} \mathrm{~J}=7.2 \mathrm{~Hz}$ ), 0.93 (t, $\left.3 \mathrm{H}, \mathrm{CH}_{2} \mathrm{CH}_{3},{ }^{3} \mathrm{~J}=7.5 \mathrm{~Hz}\right), 0.84\left(\mathrm{t}, 3 \mathrm{H}, \mathrm{CH}_{2} \mathrm{CH}_{3},{ }^{3} \mathrm{~J}=7.2 \mathrm{~Hz}\right), 0.83$ (t, $3 \mathrm{H}, \mathrm{CH}_{2} \mathrm{CH}_{3},{ }^{3} \mathrm{~J}=$ $7.2 \mathrm{~Hz}) ;{ }^{13} \mathrm{C}\left\{{ }^{1} \mathrm{H}\right\} \mathrm{NMR}\left(\mathrm{C}_{6} \mathrm{D}_{6}, 125 \mathrm{MHz}\right): \delta=190.32\left(\mathrm{dd},{ }^{1} J^{\prime} \mathrm{CRh}\right)=75.2 \mathrm{~Hz},{ }^{2} J(\mathrm{CP})=24.9$ $\mathrm{Hz}, \mathrm{CO}$ ), 187.88 (s, CO, acac), 184.33 (s, CO, acac), 159.94 (d, arom Cq-O, ${ }^{3} J(\mathrm{CP})=10.7$ $\mathrm{Hz}$ ), 158.69 (s, arom Cq-O), 155.50 (s, arom Cq-O), 155.34 (s, arom Cq-O), 142.47-120.82 (arom. C's), 100.59 (s, CH, acac), $77.13\left(\mathrm{~s}, \mathrm{OCH}_{2}\right), 76.97\left(\mathrm{~s}, \mathrm{OCH}_{2}\right), 76.94\left(\mathrm{~s}, \mathrm{OCH}_{2}\right), 32.13$ (s, $\mathrm{ArCH} \mathrm{H}_{2} \mathrm{Ar}$ ), 31.59 (s, $\mathrm{ArCH} \mathrm{H}_{2} \mathrm{Ar}$ ), 31.54 (s, $\mathrm{ArCH} \mathrm{H}_{2} \mathrm{Ar}$ ), $29.74\left(\mathrm{~d}, \mathrm{ArCH} \mathrm{H}_{2} \mathrm{Ar},{ }^{3} J(\mathrm{CP})=5.3\right.$ $\mathrm{Hz}), 27.40\left(\mathrm{~d},{ }^{3} J(\mathrm{CRh})=5.4 \mathrm{~Hz}, \mathrm{CH}_{3}\right.$, acac), $27.03\left(\mathrm{~s}, \mathrm{CH}_{3}, \mathrm{acac}\right), 23.93\left(\mathrm{CH}_{2} \mathrm{CH}_{3}\right), 23.73$ $\left(\mathrm{CH}_{2} \mathrm{CH}_{3}\right), 23.49\left(\mathrm{CH}_{2} \mathrm{CH}_{3}\right), 22.07\left(\mathrm{CH}_{2} \mathrm{CH}_{3}\right), 11.07\left(\mathrm{CH}_{2} \mathrm{CH}_{3}\right), 10.83\left(\mathrm{CH}_{2} \mathrm{CH}_{3}\right), 10.22$ $\left(\mathrm{CH}_{2} \mathrm{CH}_{3}\right), 10.12\left(\mathrm{CH}_{2} \mathrm{CH}_{3}\right) ;{ }^{31} \mathrm{P}\left\{{ }^{1} \mathrm{H}\right\} \mathrm{NMR}\left(\mathrm{C}_{6} \mathrm{D}_{6}, 121 \mathrm{MHz}\right): \delta=56.0\left(\mathrm{~d}, \mathrm{PPh},{ }^{1} J(\mathrm{PRh})=\right.$ $172 \mathrm{~Hz}$ ) ppm; IR: $v=1975$ (strong, CO), 1579 (medium s, acac), 1516 (ms, acac) $\mathrm{cm}^{-1}$; elemental analysis calcd (\%) for $\mathrm{C}_{58} \mathrm{H}_{62} \mathrm{O}_{7} \mathrm{PRh}(\mathrm{Mr}=1004.99)$ : C 69.32, $\mathrm{H}$ 6.22; found (\%): $\mathrm{C}$ 68.36, H 6.02. Despite repeated elemental analyses, the values obtained for the $\mathrm{C}$ analysis were not satisfactory.

X-ray Crystal Structure Determination for Gold Complex 4: Single crystals of 4 suitable for X-ray analysis were obtained by slow diffusion of methanol into a chloroform solution of 
the complex. Crystal data: $\mathrm{C}_{58} \mathrm{H}_{61} \mathrm{AuClO}_{4} \mathrm{P}, M \mathrm{r}=1085.46 \mathrm{~g} \mathrm{~mol}^{-1}$, triclinic, space group $P-1$, $a=11.288(5) \AA, b=11.576(5) \AA, c=20.999(5) \AA, \alpha=87.574(5)^{\circ}, \beta=86.443(5)^{\circ}, \gamma=$ $64.980(5)^{\circ}, V=2481.3(16) \AA^{3}, Z=2, D=1.453 \mathrm{~g} \mathrm{~cm}^{-3}, \mu=3.097 \mathrm{~mm}^{-1}, F(000)=1104.0, T$ $=173(2) \mathrm{K}$. The sample was studied on a Kappa APEX II diffractometer (graphite monochromated Mo- $K_{\alpha}$ radiation, $\lambda=0.71073 \AA$ ). The data collection $\left(2 \theta_{\max }=59.8^{\circ}\right.$, omega scan frames by using $0.7^{\circ}$ omega rotation and $30 \mathrm{~s}$ per frame, range $h k l: h-15,15 k-16,16 l-$ $29,29)$ gave 53983 reflections. The structure was solved with SIR- 97, ${ }^{[25]}$ which revealed the non-hydrogen atoms of the molecule. After anisotropic refinement, all of the hydrogen atoms were found with a Fourier difference map. The structure was refined with SHELXL97 ${ }^{[26]}$ by the full-matrix least-square techniques (use of $F$ square magnitude; $x, y, z$, ij for $\mathrm{C}, \mathrm{O}$ and $\mathrm{P}$ atoms; $x, y, z$ in riding mode for $\mathrm{H}$ atoms); 590 variables and 14382 observations with $I>2.0$ $\sigma(I)$; calcd. $w=1 /\left[\sigma^{2}\left(F_{\mathrm{o}}^{2}\right)+(0.0224 P)^{2}+1.5095 P\right]$ where $P=\left(F_{\mathrm{o}}^{2}+2 F_{\mathrm{c}}^{2}\right) / 3$, with the resulting $R=0.0299, R_{\mathrm{W}}=0.0589$ and $S_{\mathrm{W}}=1.048, \Delta \rho<1.810 \mathrm{e} \AA^{-3}$. CCDC 1455340 .

X-ray Crystal Structure Determination for Phosphole Oxide 9: Single crystals of 9 suitable for X-ray analysis were obtained by slow diffusion of methanol into a chloroform solution of the complex. Crystal data: $\mathrm{C}_{52} \mathrm{H}_{55} \mathrm{ClO}_{5} \mathrm{P}, M \mathrm{r}=790.93 \mathrm{~g} \mathrm{~mol}^{-1}$, cubic, space group $I 2{ }_{1} 3, a=38.0572(4) \AA, b=38.0572(4) \AA, c=38.0572(4) \AA, \alpha=90, \beta=90^{\circ}, \gamma=90, V=$ $55120.2(17) \AA^{3}, Z=48, D=1.144 \mathrm{~g} \mathrm{~cm}^{-3}, \mu=0.880 \mathrm{~mm}^{-1}, F(000)=20256, T=173(2) \mathrm{K}$. The sample was studied on a Kappa APEX II diffractometer (graphite monochromated Mo- $K_{\alpha}$ radiation, $\lambda=0.71073 \AA$ ). The data collection $\left(2 \theta_{\max }=133.4^{\circ}\right.$, omega scan frames by using $0.7^{\circ}$ omega rotation and $30 \mathrm{~s}$ per frame, range $\left.h k l: h-43,28 k-44,45 l-45,42\right)$ gave 161417 reflections. The structure was solved with SIR- 97, ${ }^{[25]}$ which revealed the non-hydrogen atoms of the molecule. After anisotropic refinement, all of the hydrogen atoms were found with a Fourier difference map. The structure was refined with SHELXL97 ${ }^{[26]}$ by the full-matrix least-square techniques (use of $F$ square magnitude; $x, y, z$, ij for $\mathrm{C}, \mathrm{O}$ and $\mathrm{P}$ atoms; $x, y, z$ in riding mode for $\mathrm{H}$ atoms); 1074 variables and 16277 observations with $I>2.0 \sigma(I)$; calcd. $w=$ $1 /\left[\sigma^{2}\left(F_{\mathrm{o}}{ }^{2}\right)+(0.0760 P)^{2}+11.7206 P\right]$ where $P=\left(F_{\mathrm{o}}{ }^{2}+2 F_{\mathrm{c}}{ }^{2}\right) / 3$, with the resulting $R=0.0482$, $R_{\mathrm{W}}=0.1279$ and $S_{\mathrm{W}}=1.054, \Delta \rho<0.403$ e $\AA^{-3}$. CCDC 1455997 .

X-ray Crystal Structure Determination for Palladium Complex 11: Single crystals of 11 suitable for X-ray analysis were obtained by slow diffusion of methanol into a chloroform solution of the complex. Crystal data: $\mathrm{C}_{62} \mathrm{H}_{63} \mathrm{ClNO}_{4} \mathrm{PPd}, \mathrm{Mr}=1058.96 \mathrm{~g} \mathrm{~mol}^{-1}$, triclinic, space group $P-1, a=9.8908(7) \AA, b=19.6964(14) \AA, c=27.456(2) \AA, \alpha=94.474(2), \beta=$ 90.746(2) ${ }^{\circ}, \gamma=91.791(2), V=5329.2(7) \AA^{3}, Z=4, D=1.320 \mathrm{~g} \mathrm{~cm}^{-3}, \mu=0.477 \mathrm{~mm}^{-1}$, $F(000)=2208, T=173(2) \mathrm{K}$. The sample was studied on a Kappa APEX II diffractometer (graphite monochromated Mo- $K_{\alpha}$ radiation, $\lambda=0.71073 \AA$ ). The data collection $\left(2 \theta_{\max }=\right.$ $56.1^{\circ}$, omega scan frames by using $0.7^{\circ}$ omega rotation and $30 \mathrm{~s}$ per frame, range $h \mathrm{kl}: h-$ $13,13 k-25,25 l-36,36)$ gave 22333 reflections. The structure was solved with SIR- 97, ${ }^{[25]}$ which revealed the non-hydrogen atoms of the molecule. After anisotropic refinement, all of the hydrogen atoms were found with a Fourier difference map. The structure was refined with SHELXL97 ${ }^{[26]}$ by the full-matrix least-square techniques (use of $F$ square magnitude; $x, y, z$, 
ij for $\mathrm{Pd} ; \mathrm{C}, \mathrm{Cl}, \mathrm{N}, \mathrm{O}$ and $\mathrm{P}$ atoms; $x, y, z$ in riding mode for $\mathrm{H}$ atoms); 1298 variables and 25707 observations with $I>2.0 \sigma(I)$; calcd. $w=1 /\left[\sigma^{2}\left(F_{\mathrm{o}}{ }^{2}\right)+(0.0537 P)^{2}+15.5771 P\right]$ where $P$ $=\left(F_{\mathrm{o}}^{2}+2 F_{\mathrm{c}}^{2}\right) / 3$, with the resulting $R=0.0782, R_{\mathrm{W}}=0.1776$ and $S_{\mathrm{W}}=1.060, \Delta \rho<2.058$ e $\AA^{-3}$. CCDC 1545341 .

X-ray Crystal Structure Determination for Gold Complex 12: Single crystals of 12 suitable for X-ray analysis were obtained by slow diffusion of methanol into a chloroform solution of the complex. Crystal data: $\mathrm{C}_{52} \mathrm{H}_{55} \mathrm{AuClO}_{4} \mathrm{P}, M \mathrm{r}=1007.34 \mathrm{~g} \mathrm{~mol}^{-1}$, monoclinic, space group $P 2_{1}, a=9.0854(9) \AA, b=18.1789(8) \AA, c=13.8937(15) \AA, \beta=99.456(2)^{\circ}, V=$ $2263.5(4) \AA^{3}, Z=2, D=1.478 \mathrm{mg} \mathrm{m}^{-3}, \mu=3.389 \mathrm{~mm}^{-1}, F(000)=1020, T=173(2) \mathrm{K}$. The sample was studied on a Kappa APEX II diffractometer (graphite monochromated Mo- $K_{\alpha}$ radiation, $\lambda=0.71073 \AA$ ). The data collection $\left(2 \theta_{\max }=5.8^{\circ}\right.$, omega scan frames by using $0.7^{\circ}$ omega rotation and $30 \mathrm{~s}$ per frame, range $h k l: h-11,11 k-23,24 l-18,18)$ gave 22333 reflections. The structure was solved with SIR-97, ${ }^{[25]}$ which revealed the non-hydrogen atoms of the molecule. After anisotropic refinement, all of the hydrogen atoms were found with a Fourier difference map. The structure was refined with SHELXL97 ${ }^{[26]}$ by the full-matrix least-square techniques (use of $F$ square magnitude; $x, y, z$, ij for Au; $\mathrm{C}, \mathrm{Cl}, \mathrm{O}$ and $\mathrm{P}$ atoms; $x$, $y, z$ in riding mode for $\mathrm{H}$ atoms); 531 variables and 10857 observations with $I>2.0 \sigma(I)$; calcd. $w=1 /\left[\sigma^{2}\left(F_{\mathrm{o}}{ }^{2}\right)\right.$, with the resulting $R=0.0497, R_{\mathrm{W}}=0.0825$ and $S_{\mathrm{W}}=1.023, \Delta \rho<2.370$ e $\AA^{-3}$. CCDC 1545342 .

\section{Computational details}

Calculations were performed using the ADF 2013 package. ${ }^{[27]}$ Slater type orbitals were used with all-electron double- $\zeta$ quality basis sets at DFT level with B3LYP functional. ${ }^{[28]}$ Dispersive interactions were taken into account through the recent Grimme corrections with damping function. ${ }^{[29]}$ Scalar relativistic effects were included through ZORA Hamiltonian. ${ }^{[30]}$ Full geometry optimization was performed on each structures. The NMR shielding of the protons of the methylene groups was computed using ADF NMR modules. Single points with Gaussian 09 package $^{[31]}$ were done at DFT level with B3LYP functional on ADF optimized structure in order to compute wavefunctions suitable for topological analyses. The atoms were described by the def2-SV basis sets on all atoms ${ }^{[32]}$ and associated pseudopotentials for Rh, Pd and Au cations. ${ }^{[33]}$ The weak interactions were studied through the NCI analysis of the Gaussian wavefunction. ${ }^{[34]}$

\section{References}

[1] a) C. Wieser, C. B. Dieleman and D. Matt, Coord. Chem. Rev. 1997, 165, 93-161; b) S. Steyer, C. Jeunesse, D. Armspach, D. Matt and J. Harrowfield, in: Z. Asfari, V. Böhmer, J. Harrowfield, J. Vicens (Eds.), Calixarenes 2001, pp 513-535; c) D. M. Homden and C. Redshaw, Chem. Rev. 2008, 108, 5086-5130; d) C. J. Cobley and P. G. Pringle, Catal. Sci. Technol. 2011, 1, 239-242; e) A. Marson, P. W. N. M. van Leeuwen and P. C. J. Kamer; f) D. Sémeril and D. Matt, Coord. Chem. Rev. 2014, 279, 58-95. 
[2] a) R. Paciello, L. Siggel and M. Röper, Angew. Chem. Int. Ed. 1999, 38, 1920-1923; b) F. J. Parlevliet, C. Kiener, J. Fraanje, K. Goubitz, M. Lutz, A. L. Spek, P. C. J. Kamer and P. W. N. M. van Leeuwen, J. Chem. Soc. Dalton 2000, 1113-1122; c) C. Dieleman, S. Steyer, C. Jeunesse and D. Matt, J. Chem. Soc. Dalton 2001, 2508-2517; d) M. Lejeune, D. Sémeril, C. Jeunesse, D. Matt, F. Peruch, P. L. Lutz and L. Ricard, Chem. Eur. J. 2004, 10, 5354-5360; e) D. Sémeril, C. Jeunesse, D. Matt and L. Toupet, Angew. Chem. Int. Ed. 2006, 45, 5810-5814; f) L. Monnereau, D. Sémeril and D. Matt, Green Chem. 2010, 12, 1670-1673; g) L. Monnereau, D. Sémeril, D. Matt and L. Toupet, Chem. Eur. J. 2010, 16, 9237-9247; h) L. Monnereau, D. Sémeril and D. Matt, Chem. Commun. 2011, 47, 6626-6628; i) M. Jouffroy, R. Gramage-Doria, D. Armspach, D. Sémeril, W. Oberhauser, D. Matt and L. Toupet, Angew. Chem. Int. Ed. 2014, 53, 3937-3940; j) M. Jouffroy, D. Armspach, D. Matt, K. Osakada and D. Takeuchi, Angew. Chem. Int. Ed. 2016, 55, 8367-8370.

[3] a) K. Ito, M. P. Schramm, M. Kanaura, M. Ide, N. Endo and T. Iwasawa, Tetrahedron Letters 2016, 57, 233-236; b) M. Kanaura, N. Endo, M. P. Schramm and T. Iwasawa, Eur. J. Org. Chem. 2016, 4970-4975.

[4] a) D. Sémeril, C. Jeunesse and D. Matt, C. R. Chimie 2008, 11, 583-594; b) N. Khiri, E. Bertrand, M. J. Ondel-Eymin, Y. Rousselin, J. Bayardon, P. D. Harvey and S. Jugé, Organometallics 2010, 29, 3622-3631; c) L. Monnereau, D. Sémeril, D. Matt and L. Toupet, Transit. Metal Chem. 2013, 38, 821-825.

[5] a) Y. Kuninobu, T. Yoshida and K. Takai, J. Org. Chem. 2011, 76, 7370-7376; b) V. Diemer, A. Berthelot, J. Bayardon, S. Jugé, F. R. Leroux and F. Colobert, J. Org. Chem. 2012, 77, 6117-6127; c) K. Fourmy, D. H. Nguyen, O. Dechy-Cabaret and M. Gouygou, Catal. Sci. Technol. 2015, 5, 4289-4323; d) T. Okada, Y. Unoh, T. Satoh and M. Miura, Chem. Letters 2015, 44, 1598-1600.

[6] F. Elaieb, A. Hedhli, D. Sémeril, D. Matt and J. Harrowfield, Eur. J. Org. Chem. 2016, 3103-3108.

[7] K. Baba, M. Tobisu and N. Chatani, Angew. Chem. Int. Ed. 2013, 52, 11892-11895.

[8] A. Casnati, M. Fochi, P. Minari, A. Pochini, M. Reggiani, R. Ungaro and D. N. Reinhoudt, Gazz. Chim. Ital. 1996, 126, 99-106.

[9] C. D. Gutsche, in Calixarenes, Monographs in Supramolecular Chemistry, J. F. Stoddart Ed., Royal Society of Chemistry, 1989, Cambridge, UK, p111.

[10] E. Herrero-Gómez, C. Nieto-Oberhuber, S. López, J. Benet-Buchholz and A. M. Echavarren, Angew. Chem. Int. Ed. 2006, 45, 5455-5459.

[11] S. Vuoti, M. Haukka and J. Purslainen, J. Organomet. Chem. 2007, 692, 5044-5052.

[12] F. Elaieb, A. Hedhli, D. Sémeril and D. Matt, Eur. J. Org. Chem. 2016, 1867-1873.

[13] Spartan v. 2.0.3, Wavefunction Inc., Irvine, CA.

[14] C. A. Tolman, Chem. Rev. 1977, 77, 313-348.

[15] L. Falivene, R. Credendino, A. Poater, A. Petta, L. Serra, R. Oliva, V. Scarano and L. Cavallo, Organometallics 2016, 35, 2286-2293.

[16] I. Bernal and R. A. Lalancette, C. R. Chimie 2015, 18, 929-934.

[17] P. Braunstein, D. Matt, Y. Dusausoy, J. Fischer, A. Mitschler and L. Ricard, J. Am. Chem. Soc. 1981, 103, 5115-5125.

[18] a) P. S. Pregosin, NMR in Organometallic Chemistry, 2012, Wiley-VCH, Weinheim, Germany, pp251-252; b) M. Teci, E. Brenner, D. Matt and L. Toupet, Eur. J. Inorg. Chem. 2013, 2841-2848.

[19] A. Oukhrib, L. Bonnafoux, A. Panossian, S. Waifang, D. H. Nguyen, M. Urrutigoity, F. Colobert, M. Gouygou and F. R. Leroux, Tetrahedron 2014, 70, 1431-1436.

[20] M. Montag, I. Efremenko, R. Cohen, G. Leitus, L. J. W. Shimon, Y. Diskin-Posner, Y. Ben-David, J. M. L. Martin and D. Milstein, Chem. Eur. J. 2008, 14, 8183-8194. 
[21] H. C. Su, O. Fadhel, C. J. Yang, T. Y. Cho, C. Fave, M. Hissler, C. C. Wu and R. Réau, J. Am. Chem. Soc. 2006, 128, 983-995.

[22] R. Usón, A. Laguna and M. Laguna, Inorg. Synthesis 1989, 26, 85-87.

[23] F. R. Hartley, The Chemistry of Platinum and Palladium, Wiley, New York, 1973.

[24] A. C. Cope and E. C. Friedrich, J. Am. Chem. Soc. 1968, 90, 909-913.

[25] A. Altomare, M. C. Burla, M. Camalli, G. Cascarano, C. Giacovazzo, A. Guagliardi, A. G. G. Moliterni and G. Polidori, J. Appl. Crystallogr. 1998, 31, 74-77.

[26] G. M. Sheldrick, SHELXL-97, Program for the Refinement of Crystal Structures, University of Göttingen, Germany, 1997.

[27] ADF2013, SCM, Theoretical Chemistry, Vrije Universiteit, Amsterdam, The Netherlands, http://www.scm.com.

[28] P. J. Stephens, F. J. Devlin, C. F. Chabalowski and M. J. Frisch, J. Phys. Chem. 1994, 98, 11623-11627.

[29] a) S. Grimme, J. Antony, S. Ehrlich and H. Krieg, J. Chem. Phys. 2010, 132, 154104; b)

S. Grimme, S. Ehrlich and L. Goerigk, J. Comput. Chem. 2011, 32, 1456-1465.

[30] E. van Lenthe, A. Ehlers and E. J. Baerends, J. Chem. Phys. 1999, 110, 8943-8953.

[31] Gaussian 09, Revision D.01, M. J. Frisch, G. W. Trucks, H. B. Schlegel, G. E. Scuseria, M. A. Robb, J. R. Cheeseman, G. Scalmani, V. Barone, B. Mennucci, G. A. Petersson, H. Nakatsuji, M. Caricato, X. Li, H. P. Hratchian, A. F. Izmaylov, J. Bloino, G. Zheng, J. L. Sonnenberg, M. Hada, M. Ehara, K. Toyota, R. Fukuda, J. Hasegawa, M. Ishida, T. Nakajima, Y. Honda, O. Kitao, H. Nakai, T. Vreven, J. A. Montgomery, Jr., J. E. Peralta, F. Ogliaro, M. Bearpark, J. J. Heyd, E. Brothers, K. N. Kudin, V. N. Staroverov, R. Kobayashi, J. Normand, K. Raghavachari, A. Rendell, J. C. Burant, S. S. Iyengar, J. Tomasi, M. Cossi, N. Rega, J. M. Millam, M. Klene, J. E. Knox, J. B. Cross, V. Bakken, C. Adamo, J. Jaramillo, R. Gomperts, R. E. Stratmann, O. Yazyev, A. J. Austin, R. Cammi, C. Pomelli, J. W. Ochterski, R. L. Martin, K. Morokuma, V. G. Zakrzewski, G. A. Voth, P. Salvador, J. J. Dannenberg, S. Dapprich, A. D. Daniels, Ö. Farkas, J. B. Foresman, J. V. Ortiz, J. Cioslowski, and D. J. Fox, Gaussian, Inc., Wallingford CT, 2009.

[32] A. Schäfer, H. Horn and R. Ahlrichs, J. Chem. Phys. 1992, 97, 2571-2577.

[33] K. Eichkorn, F. Weigend, O. Treutler and R. Ahlrichs, Theor. Chem. Acc. 1997, 97, 119124.

[34] J. Contreras-Garcia, E. R. Johnson, S. Keinan, R. Chaudret, J. P. Piquemal, D. N. Beratan and W. T. Yang, J. Chem. Theory Comput. 2011, 7, 625-632. 